Discussion Paper No. 18-005

\title{
Public Investment in R\&D in Reaction to Economic Crises - A Longitudinal Study for OECD Countries
}

Maikel Pellens, Bettina Peters, Martin Hud, Christian Rammer, Georg Licht

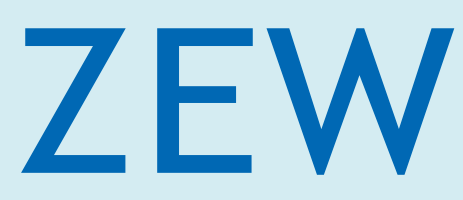

Zentrum für Europäische Wirtschaftsforschung $\mathrm{GmbH}$

Centre for European Economic Research 
Discussion Paper No. 18-005

\title{
Public Investment in R\&D in Reaction to Economic Crises - A Longitudinal Study for OECD Countries
}

\author{
Maikel Pellens, Bettina Peters, Martin Hud, \\ Christian Rammer, Georg Licht
}

Download this ZEW Discussion Paper from our ftp server:

http://ftp.zew.de/pub/zew-docs/dp/dp18005.pdf

Die Discussion Papers dienen einer möglichst schnellen Verbreitung von neueren Forschungsarbeiten des ZEW. Die Beiträge liegen in alleiniger Verantwortung der Autoren und stellen nicht notwendigerweise die Meinung des ZEW dar.

Discussion Papers are intended to make results of ZEW research promptly available to other economists in order to encourage discussion and suggestions for revisions. The authors are solely responsible for the contents which do not necessarily represent the opinion of the ZEW. 


\title{
Public Investment in R\&D in Reaction to Economic Crises - A Longitudinal Study for OECD Countries
}

\author{
Maikel Pellens, Bettina Peters, Martin Hud, Christian Rammer, Georg Licht*
}

January 2018

\begin{abstract}
The paper investigates the reaction of public R\&D spending on economic crises. We are interested in two counteracting motives: On the one hand, public R\&D spending can be seen as a means to fight the crisis, and governments may decide to increase their R\&D budgets. On the other hand, a crisis reduces public income and urges governments to cut spending, which may negatively affect public R\&D budgets. Using panel data from 26 OECD countries over the period 1995 to 2015 , we investigate how public R\&D expenditure changes over the business cycle for different types of government R\&D expenditure. On average, we find evidence for a strong pro-cyclical effect on public R\&D investments. But country heterogeneity matters. Whereas European innovation leaders and non-EU countries pursue a counter-cyclical strategy, innovation followers and moderate innovators behave pro-cyclical. This leads to an increasing innovation gap in Europe. Short-run and long-run financing conditions (budget surplus and government debt levels) also significantly affect public R\&D spending. However, there is no evidence that economic crises systematically affect the composition of public R\&D spending along different thematic areas or by beneficiaries.
\end{abstract}

JEL: H54, H12, H61

Keywords: Public R\&D expenditure, economic crisis, OECD, panel data

* Maikel Pellens, ZEW Mannheim and KU Leuven, email: pellens@zew.de; Bettina Peters, ZEW Mannheim, MaCCI and University of Luxembourg, email: b.peters@zew.de; Martin Hud, ZEW Mannheim, email: hud@zew.de; Christian Rammer, ZEW Mannheim, email: rammer@zew.de, Georg Licht, ZEW Mannheim and MaCCI, email: licht@zew.de.

Acknowledgements: This paper is an outcome of the SPINTAN project which was funded by the European Commission, Research Directorate General as part of the 7th Framework Programme, Theme 8: Socio-Economic Sciences and Humanities, Grant Agreement no 612774. Further details can be found at: www.spintan.net. 


\section{Introduction}

$R \& D$ is a main driver of long-run economic growth. Short-term adjustments of R\&D activities in response to an economic crisis may harm the building of knowledge capital stocks and reduce the longterm positive effects on productivity growth. This is particularly true if R\&D projects are stopped before completion so that parts of prior investment do not produce knowledge assets. Unbalanced cuts of $R \& D$ activities during a crisis may also hamper knowledge flows and reduce positive spillover effects of R\&D.

Keeping investment into $R \& D$ at a high level even if the economic situation is tough should hence be a policy priority. Governments may react to an economic crisis in different ways. One reaction is to help private firms maintain their level of R\&D expenditure by providing (additional) R\&D subsidies and other forms of direct or indirect R\&D support. Another way to keep R\&D expenditure high during crisis is to extend R\&D activities in the public sector (universities, government research labs) to compensate for a likely reduction in the private sector.

Increasing government support for private R\&D and expanding public R\&D budgets during an economic crisis is challenged by a pressure for fiscal consolidation. As economic activities decrease, public income from taxes will decrease too, calling for austerity measures. In such a situation, governments may opt to focus their R\&D spending policy on those targets (both in terms of thematic areas and R\&D actors) which they feel most urgently need public support or for which they expect the most significant macro-economic impact. But governments may also opt to cut R\&D budgets in response to falling tax income as short-term consequences of such cuts may be less severe for the economy compared to other areas such as social security or labour market interventions. Such cuts may be easier to realise for discretionary expenditure such as subsidies and more difficult for institutional funding of research infrastructures.

Against this background, the present paper attempts to investigate the following research questions:

- How do economic crises influence the overall level and growth of public R\&D spending?

- Do economic crises lead to shifts in the composition of public R\&D expenditures across different thematic areas?

- Are there any business cycle induced redistributions across different recipients of public R\&D expenditure?

In answering these research questions, we put a special focus on the question as well whether governments in Europe and in OECD countries outside Europe react differently to the crisis in terms of level and composition of public R\&D spending.

We use data on government R\&D spending for 26 OECD countries for the period 1995-2015. Employing the Main Science and Technology Indicators (MSTI) database, we distinguish the following categories of government R\&D spending: 
- Total public R\&D funding broken down by recipients: business enterprise sector, higher education sector, government sector

- Total government appropriations or outlays for R\&D, broken down by thematic focus, distinguishing defence, health/environment, space, education/society, economic development, non-oriented R\&D, and general university funds.

We measure business cycle fluctuations and economic crisis by the most simple measure, the change in real GDP. As government R\&D spending data are only available on an annual base, we use annual change in GDP. In addition, we use different business cycle indicators. Most importantly, an economic crisis (recession) marks a year with negative growth in real GDP. We also consider the impact of a budget surplus or deficit as well as the level of government debt. Both variables reflect governments' financing conditions but are also highly correlated with the business cycle.

Our regression results demonstrate four major findings: First, there is strong pro-cyclical effect on public R\&D investments. An increase in GDP by 1 percent leads to a subsequent increase in public $R \& D$ spending (GBAORD) by roughly 0.15 to 0.2 percent. Furthermore, the growth rate of GBAORD is significantly lower in a recession. There is, however, impressive evidence that countries react differently to recessions. In particular, European innovation leaders and non-EU countries pursue a counter-cyclical strategy whereas innovation followers and moderate innovators behave pro-cyclical. As a result, we have observed an increasing innovation gap between innovation leaders and moderate innovators in Europe due to the most recent 2008 crisis. Second, short-run and long-run financing conditions (budget surplus and government debt levels) affect public R\&D spending significantly. Third, economic crises do not systematically affect the composition of GBAORD spending along different thematic areas. And finally, there is no evidence for a business cycle induced redistribution of public $R \& D$ expenditures across recipients.

In the next section, we briefly discuss the way business cycle fluctuations, and economic crisis in particular, may influence governments' decisions to provide funding for R\&D for different economic sectors and different purposes. Section 3 describes the data we use and the econometric approach. Section 4 presents and discusses our estimation results. Policy conclusions are provided in the final section.

\section{Literature Review}

Business cycle impacts on R\&D expenditure of firms have been analysed both on a theoretical level (see Barlevy 2007, Shleifer 1987, Francois and Lloyd-Ellis 2003, 2009) and in many empirical studies (see Geroski and Walters 1995, Fatas 2000, Wälde and Woitek 2004, Comin and Gertler 2006, Rafferty and Funk 2008, Bovha-Padilla et al. 2009, Aghion et al. 2010, 2012, Ouyang 2011, Filippetti and Archibugi 2011, López-Garcia et al. 2012, Fabrizio and Tsolmon 2014, Arvanitis and Woerter 2014, Hud and Rammer 2015, Giebel and Kraft 2015). Most studies find a pro-cyclical behaviour of R\&D in firms, though opportunity costs may lead to counter-cyclical R\&D as costs of (long-term) R\&D investment compared to (short-term) capital investment costs tend to be lower in recessions and higher in boom periods (see Bean 1990, Gali and Hammour 1991, Saint-Paul 1993, Aghion and Saint-Paul 1998). 
Less emphasis has been given to the analysis of business cycle impacts on public R\&D expenditure, particularly with reference to government funding for R\&D. With the deep financial and economic crisis starting in 2007, the attention towards government decisions on R\&D budgets has increased substantially, however (see European Commission 2011, OECD 2012). A main issue concerns the direction of government response. Arguments for a counter-cyclical reaction on the economic crisis refer to Keynesian economics which stress the need to stabilize the economy. By increasing government spending during recessions, reducing tax burden and shifting budgets towards a deficit governments attempt to increase consumption and investment (Romer 1993). In case of R\&D, more generous R\&D tax incentives and additional subsidies for R\&D can help firms to maintain their R\&D investment level (Paunov 2012, Hud and Hussinger 2015) and may facilitate an endogenous economic upturn by stimulating the production of demand-generating innovations during a crisis (Hud and Rammer 2015). From a neoclassical perspective, the optimal government reaction depends on the degree of substitutability in utility between public and private spending (Arreaza et al. 1999, Lane 2003). If both are substitutes, government spending should behave counter-cyclically whereas in case of complementarity, a pro-cyclical pattern would emerge. Empirical studies are inconclusive whether public and private R\&D are complements or substitutes (David et al 2000), providing little help for government decisions.

A pro-cyclical pattern of government spending on R\&D will be reinforced by decreasing tax income of governments during a recession, reducing the funds available for additional expenditure (Makkonen 2013). In case of a pro-cyclical response, government cuts in R\&D budgets may not hit all types of R\&D equally. Kim (2014) argues that funds and programs for basic research may be more likely become targets for budgetary cuts given their relatively high uncertainty and long development time. At the same time, most basic research is conducted in universities and government labs, based either on institutional funding or long-term research projects which limits the potential for short-term cuts in $R \& D$ expenditure.

In a descriptive analysis of changes in governments' R\&D budgets after the economic crisis in 2008/09, Makkonen (2013) finds that the majority of EU countries showed a pro-cyclical reaction. In most countries R\&D budgets followed the general trend of decreasing government expenditure. The economies of countries with a pro-cyclical reaction tend to be less innovation oriented and show a weaker fiscal performance. Among the countries with a counter-cyclical pattern of government R\&D spending are those that are characterised as innovation leaders in Europe (Germany, Sweden, Denmark) though also several less innovation oriented countries followed a counter-cyclical pattern (Portugal, Spain, Italy, Greece) (Veugelers 2014).

Izsak et al. (2013) analysed government reactions on the crisis in terms of policy mix and policy priorities in the field of R\&D and innovation policy. They found a slight movement towards more targeted policies. Governments also tried to increase the leverage of public R\&D funding on private $R \& D$ funding. Some countries extended their R\&D tax incentives schemes. Another attempt toward more efficient use of public money reinforced public-private partnerships, particularly in areas such as energy, environment and health. Some other trends such as an increasing focus on the commercialisation of research results and the strengthening of links between public and private research as well as fostering high-tech entrepreneurship may not be linked to a crisis response but rather reflect general trends in R\&D and innovation policy. 
Veugelers (2016) also points to the issue of prioritising additional R\&D expenditure in the situation of an economic crisis. She found evidence for a focus of public R\&D support on firms that are already spending substantially on R\&D while little priority is given to firms that want to enter R\&D. Veugelers (2016) argue that such a spending strategy may limit the impacts of additional funding due to decreasing private returns on R\&D. Hud and Hussinger (2015) investigated the input additionality of increased R\&D subsidies by the German government during the economic crisis in 2009. They find positive effects, but the effects were smaller than in other years. The lower impact of R\&D subsidies was not caused by the mere expansion of the size of the R\&D programmes but rather reflects changes in the R\&D behaviour of recipients during the crisis.

In an assessment of research and innovation policy response to the financial and economic crisis 200709, the OECD (2012) concluded that most governments of OECD countries were resilient to the global financial crisis with respect to R\&D spending. Most countries did not cut their R\&D spending in 2009, the year of the most severe direct economic impacts of the crisis. Despite this general resilience, there have been substantial differences in the actual policy response. Some countries implemented recovery policies which mainly supported ongoing innovation policy initiatives, e.g. by extending the volume of programmes. Other countries deliberately avoided any change to their programmes and policies in order to safeguard continuity and avoid uncertainty among R\&D actors about the long-term priorities of R\&D and innovation policy. In a few countries, the crisis led to new government innovation initiatives and projects. Countries that actively tried to support private R\&D during the crisis focused on easing access to credit and venture capital, adjusted R\&D tax incentive schemes, set priorities in thematic areas assumed to be of particular importance for a country's competitiveness and welfare (e.g. health, environment), focussed on R\&D support for SMEs, or addressed perceived weaknesses of national innovation systems (e.g. public-private cooperation). The OECD (2012) identified a number of challenges for these policy responses. Timely response was difficult in some countries due to time consuming budgeting processes. Providing fund for new initiatives requires time for planning and preparation. A lack of "good projects" also limited the implementation of new effective funding initiatives in short term. The uptake of policy measures by the private sector was sometimes quite restricted due to high uncertainty about the future economic prospects. Public procurement of innovation or public R\&D contracts were used to limit the need of private co-funding of government support.

\section{Data and Methodology}

\subsection{Data on Government R\&D Expenditures}

For the empirical analysis we need information on government R\&D expenditures which we gather from two different data sources. Both data sources are available in the most recent MSTI 2015-2 data base (OECD 2016). This data base contains information on Government Budget Appropriation and Outlays for R\&D (GBAORD). GBAORD contains all government R\&D spending in central or federal government budgets. The main virtue of GBAORD data relates to the fact that it is derived from the annual budget and therefore provides consistent, reliable and most up-to-date figures. GBAORD data furthermore allows a breakdown of public R\&D outlays by socio-economic thematic areas. Admittedly, this breakdown is based on the intentions or objectives of the appropriations at the time the funds are 
committed and may deviate from the actual content of the projects concerned. With respect to the thematic areas GBAORD data can be split into defence and civil government R\&D outlays. Within the latter group, government R\&D outlays are broken down into R\&D outlays for economic development programmes, health and environment, education and social programmes, space programmes, nonoriented research programmes and general university funds. A flaw of GBAORD data is that it includes all R\&D outlays in central or federal government budgets but that it potentially neglects public $R \& D$ expenditures at the regional level. More specifically, provincial or state government R\&D outlays are only included if their contribution is significant and local public R\&D expenditures are excluded. This leads to an underestimation of public R\&D expenditure that is more severe in countries with considerable regional public R\&D spending especially at the local level. We create two main dependent variables based on GBAORD data. The first variable, GBAORD, is the logarithm of the total level of government appropriations and outlays for R\&D in country $i$ and year $t$. The second variable, $G R G B A O R D$, denotes the one-year growth rate of government outlays for R\&D. In order to investigate changes in the composition of public $R \& D$ expenditures according to thematic areas over the business cycle in section 4.2 and 5.2, we additionally create shares of different GBAORD categories in total GBAORD.

As an alternative measure for government R\&D expenditures, we make use of different components of gross expenditure for R\&D (GERD) as reported by the OECD (2016). Gross expenditure for R\&D aims at covering all R\&D carried out on a national territory in the year concerned. In contrast to GBAORD , R\&D expenditure figures are based on surveys of the units carrying out the $R \& D$ and national estimates. GERD is broken down by sector of performance into Business Enterprise R\&D (BERD), Higher Education R\&D (HERD), Government R\&D (GOVERD) and Private Non-Profit institutions R\&D (PNP). It is also broken down by sources of funds into financing by private sector, by government, by other national sources and by foreign sources. We make use of the finance structure of R\&D expenditure by performing entities in order to create the variable $P u b R D$ which captures all R\&D expenditure financed by the government. PubRD is the sum of BERD financed by governments, GOVERD excluding the part which is financed by the private sector and HERD excluding the part which is financed by the private sector (in logs). PubRD is more accurate compared to the intention-based GBAORD data but only available with some time lag. GRPubRD describes the one-year growth rate of public R\&D expenditure. In order to analyse whether the structure of beneficiaries of public R\&D expenditure change over the business cycle (see section 4.3 and 5.3) time, we create the variables BPubRD, GVPubRD and HPubRD. BPubRD is the share of publicly financed R\&D in Business Enterprises in total public R\&D expenditures. GVPubRD and HPubRD are defined accordingly. In contrast to GBAORD , PubRD cannot be split by thematic areas.

\subsection{Empirical Implementation and Estimation Method}

Given our research questions, our empirical research strategy is based on four different models:

\section{Model 1: Level of Government R\&D Expenditures}

Model 1 is aimed at explaining the level of government financed R\&D expenditures of country $i$ in year $t\left(G o v R D_{i t}\right)$. GovRD $D_{i t}$ is either measured using $G B A O R D_{i t}$ or $P u b R D_{i t}$. Since many of the government $R \& D$ programmes for business enterprises are multi-annual programmes and a large proportion of 
government intramural expenditure on R\&D is spent on R\&D personnel that cannot be flexibly adjusted, we choose a dynamic specification, i.e. we include the lagged government $R \& D$ expenditures as one of the main explanatory variables.

The extent to which governments can finance $R \& D$ expenditures is influenced by budgetary developments. From a short-run perspective, public investment in $R \& D$ is likely to depend on the public budget deficit or surplus. An increasing deficit in terms of a GDP ratio means that overall government spending has increased relatively. But high deficits limit further (R\&D) spending. And in the long-run, high levels of public debts exert a strong pressure to consolidate fiscal budgets in general which might also lead to cuts in R\&D spending. Higher debt levels constrain spending because additional deficits are increasingly difficult to implement ${ }^{1}$ and interest payments consume an increasing share of the budgets. Hence, we include the lagged budget surplus in relation to GDP $\left(S U R P L U S_{i t-1}\right)^{2}$ and the lagged government debt level in relation to $\operatorname{GDP}\left(D E B T_{i t-1}\right)$ as explanatory variables in the model specification. Both variables are normalized by GDP to capture the significant differences in country size. Both variables are furthermore lagged in order to alleviate potential endogeneity problems.

Our main interest is to investigate how the business cycle affects government financed R\&D. There might be two opposing effects at work. On the one hand, governments have the responsibility for spending on other governmental tasks, particularly the social security system or unemployment insurance systems. Spending for these governmental tasks is higher during a recession than during non-recession periods so that there is a downward pressure on public R\&D spending. On the other hand, policy might in fact increase R\&D spending in a recession to trigger private investment and to act as a Keynesian style stabilizing factor. ${ }^{3}$ In order to investigate how government $R \& D$ is impacted by the business cycle, we account for lagged GDP (in logs) $\left(G D P_{i t-1}\right)$. Likewise, we used the lagged value to mitigate endogeneity problems. Lagged GDP seems furthermore justified for $G B A O R D_{i t}$ as government budgets are discussed and set the year before the expenses actually occur (Fuest and Licht 2014). $\beta_{1}$ measures the percentage increase in government financed $R \& D$ due to an increase in lagged GDP by one percent. We furthermore include the dummy variable RECESSION $N_{i t-1}$ which equals 1 if the economy of country $i$ is in a recession in year $t$ (reference category: non-recession). A recession is defined as a year in which the country-specific annual GDP growth is negative. In an alternative specification, we also allow our three main explanatory variables, $G D P_{i t-1}, S U R P L U S_{i t-1}$ and $D E B T_{i t-1}$ , to impact government R\&D spending differently in recession and non-recession years by including interaction terms. ${ }^{4}$ As a robustness check we first include a full set of business cycle indicators

\footnotetext{
${ }^{1}$ This argument is reflected in our data by a negative correlation of SURPLUS and DEBT of about -0.442 .

${ }^{2} \mathrm{~A}$ negative value indicates a budget deficit.

${ }^{3}$ In the $2008 / 2009$ crisis, this policy was pursued by several countries. The Netherlands granted R\&D tax deductions or Germany substantially increased R\&D funding for SME and e-mobility projects (Fuest and Licht 2014).

${ }^{4}$ Not surprisingly, the budgetary development and hence SURPLUS and DEBT are highly correlated with the business cycle. The annual GDP growth rate is positively correlated with SURPLUS (0.430) and negatively correlated with DEBT (-0.336). Still, multicollinearity doesn't seem to be a severe issue for estimation as all variance inflation factors are below 1.5 .
} 
BOOM, DOWNTURN and RECESSION with UPTURN being the reference category that is left out. An UPTURN is a year in which GDP growth is positive and increasing, a BOOM marks a year in which GDP growth is positive and increasing but subsequently decreasing and DOWNTURN characterizes years with positive but decreasing GDP growth. As an additional robustness check we define the twophase business cycle indicator DOWN which is 1 if GDP growth is positive but declining or negative and 0 for UPTURN and BOOM periods.

The specification furthermore accounts for the effect of long-term interest rates (in \% per annum), $I R_{i t}$. Additional control variables in some of the regressions are country group indicators and time dummies. The model further allows for unobserved heterogeneity by including country fixed effects $\alpha_{i}$ and an idiosyncratic error term $\varepsilon_{i t}$. Thus, model 1 can be summarized as follows:

$$
\begin{aligned}
\text { GovRD }_{i t}= & \gamma \text { GovRD }_{i t-1}+\beta_{1} G_{1} P_{t-1}+\beta_{2} \text { SURPLUS }_{t-1}+\beta_{3} \text { DEBT }_{t-1}+\beta_{4} \text { RECESSION }_{t-1}+\beta_{5} I_{t} \\
& + \text { Controls }+\alpha_{i}+\varepsilon_{i t}
\end{aligned}
$$

Information on GDP ,SURPLUS , DEBT and IR is also obtained from OECD. Furthermore note that $G B A O R D_{i t}, P u b R D_{i t}$ and GDP are transformed into inflation and Purchasing Power Parities (PPP) adjusted values. This implies that they are measured in constant prices and PPP, i.e. in million 2010 dollars. Data on the country-specific GDP price indices and PPP rates are likewise taken from MSTI data base (OECD 2016).

Due to its dynamic nature, model 1 is estimated using the system GMM approach (Arellano and Bover 1995, Blundell and Bond 1998 and Bond 2002). The system GMM estimator is based on a joint estimation of model 1 in first differences (in order to eliminate unobserved heterogeneity) for which we use lagged levels as instruments and in levels for which we use lagged differences as instruments.

\section{Model 2: Growth Rate of Government R\&D Expenditures}

In contrast to model 1 which is formulated in levels of government R\&D expenditures, model 2 specifies the growth rate of $G o v R D_{i t}\left(G R G o v R D_{i t}\right)$, either measured using GRGBAORD $D_{i t}$ or $G R P u b R D_{i t}$. As state dependence in growth rates turned out to be insignificant, we neglect the lagged growth rate of GovRD $D_{i t-1}$ but we allow for unobserved country heterogeneity in the growth rates of government R\&D expenditures. We furthermore assume that the growth of government R\&D expenditure depend on the lagged GDP growth, the lagged budget surplus to GDP ratio and the lagged debt to GDP ratio. That leads us to the following static fixed effects model (FE) (2):

$$
\begin{aligned}
\text { GRGovRD }_{i t}= & \beta_{1} \text { GRGDP }_{t-1}+\beta_{2} \text { SURPLUS }_{t-1}+\beta_{3} D E B T_{t-1}+\beta_{4} \text { RECESSION }_{t-1}+\beta_{5} I_{t} \\
& + \text { Controls }+\alpha_{i}+\varepsilon_{i t}
\end{aligned}
$$

\section{Model 3 and Model 4: Composition of Government R\&D Expenditures}

Model 3 and model 4 focus on how the business cycle impacts the composition of government R\&D expenditures, either broken down by thematic areas (model 3) or by beneficiaries using BPubRD $D_{i t}$, $G V P u b R D_{i t}$ and $H P u b R D_{i t}$ as dependent variables (model 4). 
Originally, information on government R\&D expenditure covers the period 1981 to 2014 ( PubRD) and 2015 (GBAORD ), respectively. However, the data only covers a very limited set of countries for the period 1981 to 1994. Particularly for the new member states only data from the mid-1990s onwards is available. Furthermore, data on government debt levels are only available from 1995 onwards. Hence, we restrict our estimation sample to the period 1995 to 2014 ( PubRD) and 1995 to 2015 (GBAORD ). Sample 1 used for GBAORD is an unbalanced panel containing 474 observations from 26 countries. The set of countries includes twenty EU countries (Austria, Belgium, Czech Republic, Denmark, Estonia, Finland, France, Germany, Greece, Hungary, Ireland, Italy, Luxembourg, Netherlands, Poland, Portugal , Slovenia, Spain, Sweden and the UK) and six non-EU countries (Australia, Canada, Israel, Japan, South Korea and the US). Sample 2 used for PubRD consists of 354 observations from 23 countries with Australia, Luxembourg and Sweden missing.

\section{Descriptive Evidence}

This section provides descriptive evidence on the evolution of government financed R\&D expenditures and their components over time. Given our research questions, we focus especially on their reaction to recession periods.

\subsection{Evolution of Government financed R\&D expenditure}

Figure 1 and Figure 2 depict the evolution of government appropriations and outlays for R\&D and of public R\&D expenditure over the period 1995 to 2015. Whereas Figure 1 presents the average annual growth rates across all countries, Figure 2 shows both indicators in relation to GDP (GBAORD / GDP and PubRD/GDP). As expected GBAORD figures are slightly below public R\&D expenditure (see Figure 2 ) as GBAORD focusses mainly on central government expenditures and neglects some government outlays for R\&D at the regional level.

The average annual growth rate of government budget appropriations and outlays for R\&D amounts to 3.86 percent over the period 1995-2015, whereas public R\&D expenditure has grown on average by 3.71 percent per annum. Between 1995 and 2007 both indicators for government financed R\&D demonstrate positive and high annual growth rates, mainly varying between 2.5 and 6 percent. This growth in government financed R\&D is accompanied by a similar growth in GDP. Figure 2 reveals that both indicators for government financed R\&D expenditures demonstrate a rather stable development in relation to GDP between 1995 and 2007, i.e. in the pre-period of the severe 2008 economic crisis. The ratios of GBAORD to GDP and Public R\&D to GDP mainly vary between 0.6 and 0.65 percent across all 26 OECD countries during that period. For the crisis years 2008 and 2009, we observe a strong increase to 0.73 percent for the GBAORD to GDP ratio and 0.76 percent for the Public RD to GDP ratio. This strong rise cannot only be traced back to the sharp decline in GDP in most countries but is also substantially driven by a strong absolute increase in government financed R\&D. Actually, the 2008 average growth rates for GBAORD and Public R\&D turned out to the highest over the period under consideration, reaching respectively 8.3 and 6.9 percent.

Average annual growth of government financed R\&D has substantially slowed down in the aftermath of the economic crisis, i.e. from 2010 onwards, and has even become negative in some of the years. 
This decline has been much stronger for GBAORD than for Public R\&D, especially for the period 2010 to 2013. Figure 2 reveals that this has led to an increasing gap between GBAORD and Public R\&D. This gap has substantially widened during the period 2010 to 2014 and both indicators also show a diverging trend. Whereas the Public R\&D to GDP ratio has further increased from around 0.75 to close to 0.80 percent, the average ratio of GBAORD to GDP has slightly fallen below 0.7 again. Part of this divergence might be explained by the fact that especially Public R\&D figures for 2014 but also for 2013 and 2012 are still provisional or based on national or OECD estimates.

Figure 1: Average Annual Growth Rate of GBAORD and Public R\&D Expenditure, 1995-2015

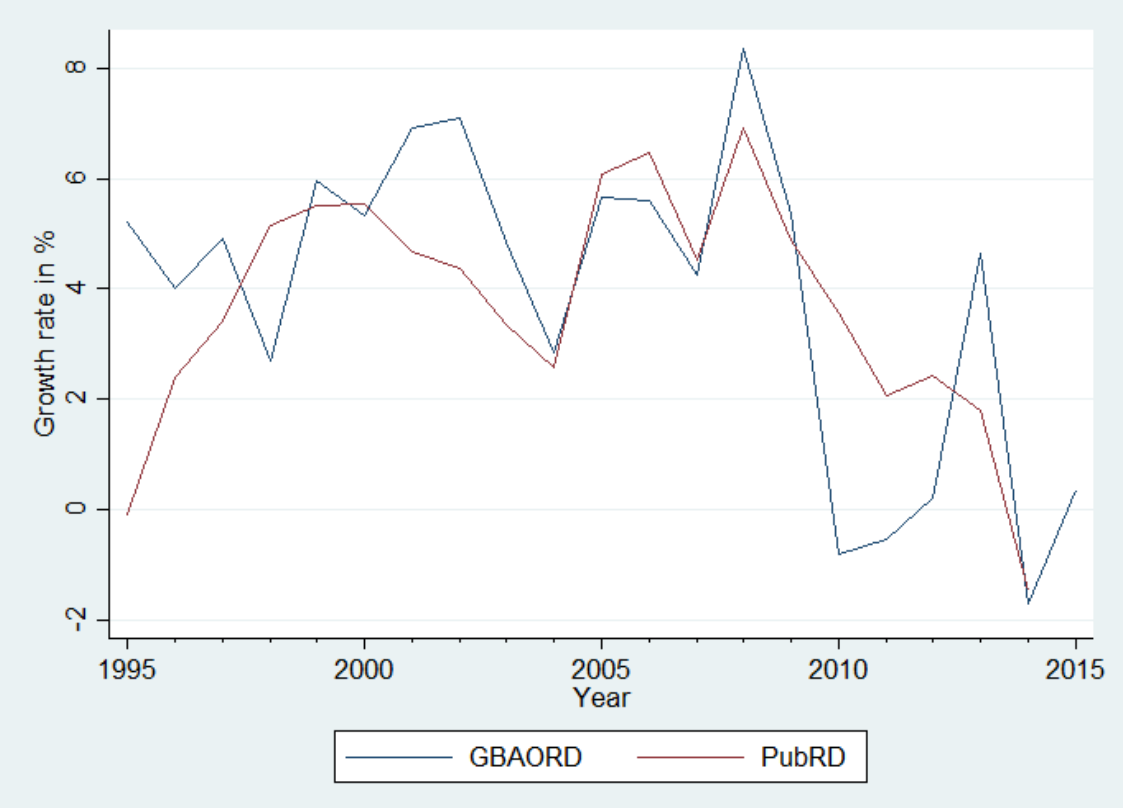

Note: Average annual growth rate of GBAORD and PubRD across all countries. For the country definition, see section 3.2

Figure 2: GBAORD and Public R\&D Expenditure in \% of GDP, 1995-2015

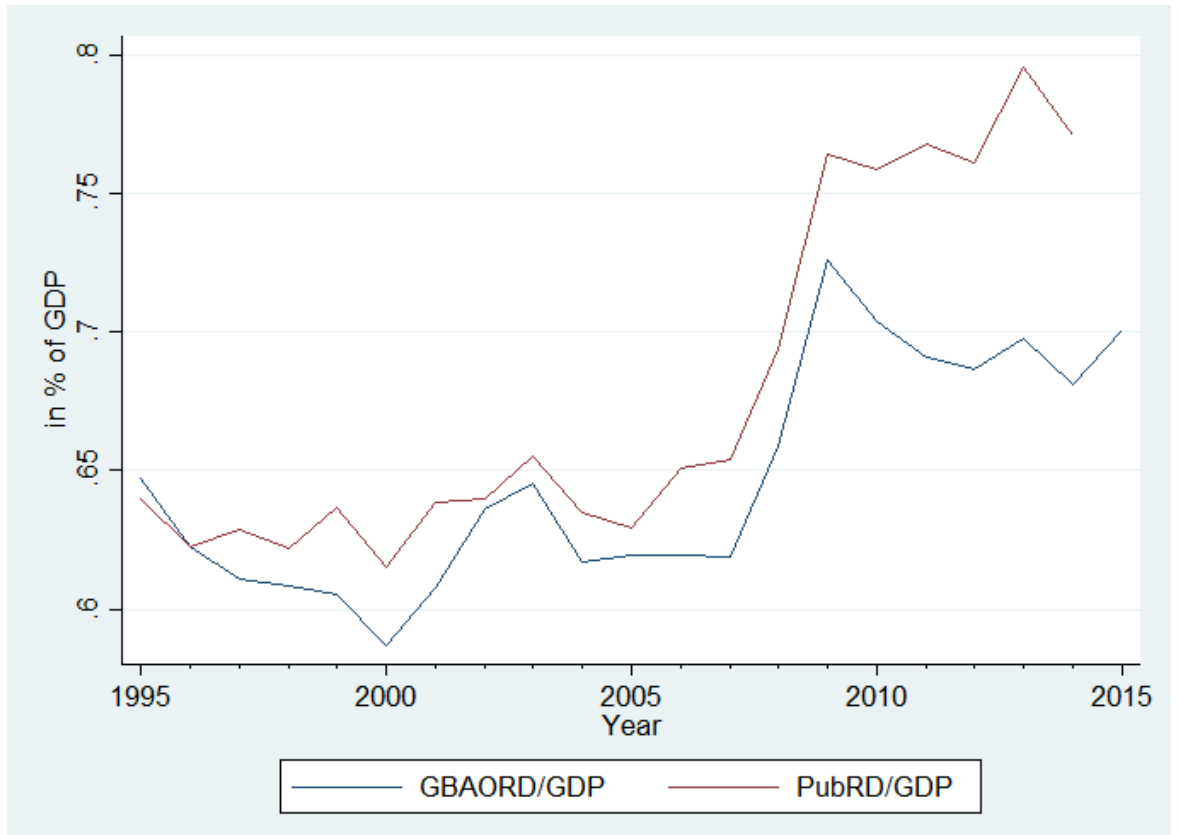

Note: Average GBAORD / GDP and PubRD / GDP across all countries. For the country definition, see section 3.2. 
Figure 1 and Figure 2 have already shown interesting changes in the crisis years 2008 and 2009 and in the post-crises period from 2010 onwards. However, countries have recovered from the economic crisis at quite different paces. In order to investigate the impact of the business cycle, it might thus be more appropriate to use country-specific business cycle indicators as those we have defined in section 3.2. Hence, Figure 3 depicts the average annual growth rates of government financed $R \& D$ expenditures by country-specific business cycle phases. Distinguishing only between upturns and downturns, no clear pattern emerges for the two indicators. Whereas GBAORD shows a pro-cyclical behaviour in a sense that it grows faster in upturn periods, Public R\&D exhibits a counter-cyclical movement. Results are consistent and much more pronounced when we compare recession with nonrecession periods. Both GBAORD and Public R\&D reveal a strong pro-cyclical development. The average annual growth is about 4 percent for both indicators in non-recession periods, but only about 1 percent in the recession period for Public R\&D and even far below for GBAORD.

Figure 3: Average Annual Growth Rate of Government Financed R\&D Expenditure by Countryspecific Business Cycle Phases, 1995-2015

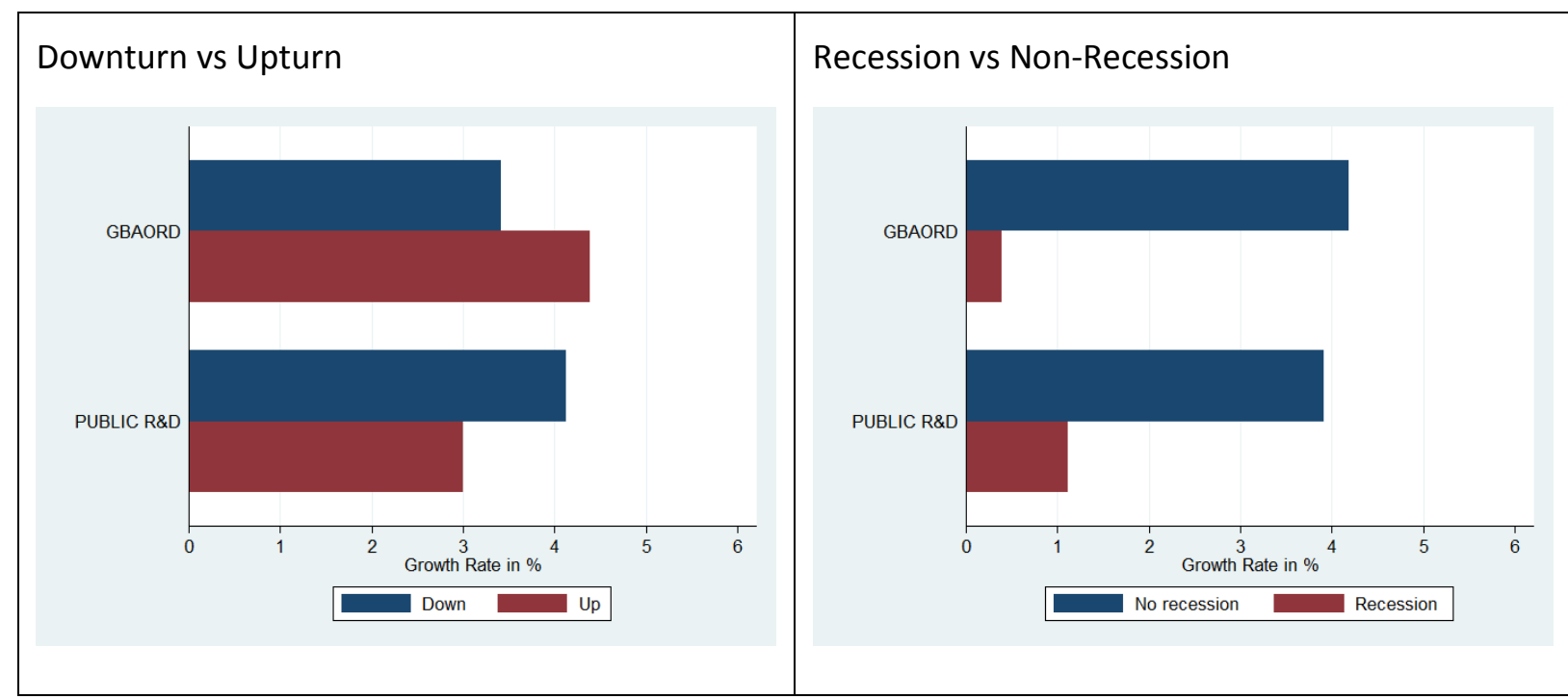

Note: Average annual growth rate of GBAORD and PubRD across all countries and different business cycle phases over the period 1995 to 2015 ( GBAORD ) and 1995 to 2014 ( PubRD ), respectively. For the country definition and definition of business cycles, see section 3.2 .

In order to investigate country-specific public responses to economic crises in more detail, Figure 4 depicts the average annual growth rate of GBAORD and Public R\&D by business cycle phase and innovation performance. The role and success of past innovation activities might be an important factor for governments when deciding on public expenditures for R\&D. For European countries, a country's innovation performance is measured using the ranking of the Innovation Union Scoreboard 2015 (European Commission, 2015). The Innovation Union Scoreboard classifies EU member states as Innovation Leaders, Innovation Followers, Moderate Innovators, or Modest Innovators based on eight key innovation related indicators. ${ }^{5}$

\footnotetext{
${ }^{5}$ In the 2015 edition, Germany, Denmark, Finland, and Sweden are ranked as Innovation Leaders. Austria, Belgium, France, Ireland, Luxembourg, the Netherlands, Slovenia, and the United Kingdom form the group of Innovation Followers. Moderate Innovators are the Czech Republic, Estonia, Greece, Hungary, Italy, Lithuania, Poland, Portugal, and Spain. Modest Innovators are Latvia and Romania (European Commission, 2015). We
} 
Figure 4: Average Annual Growth Rate of Government Financed R\&D Expenditure by Business Cycle Phase and Innovation Performance, 1995-2015

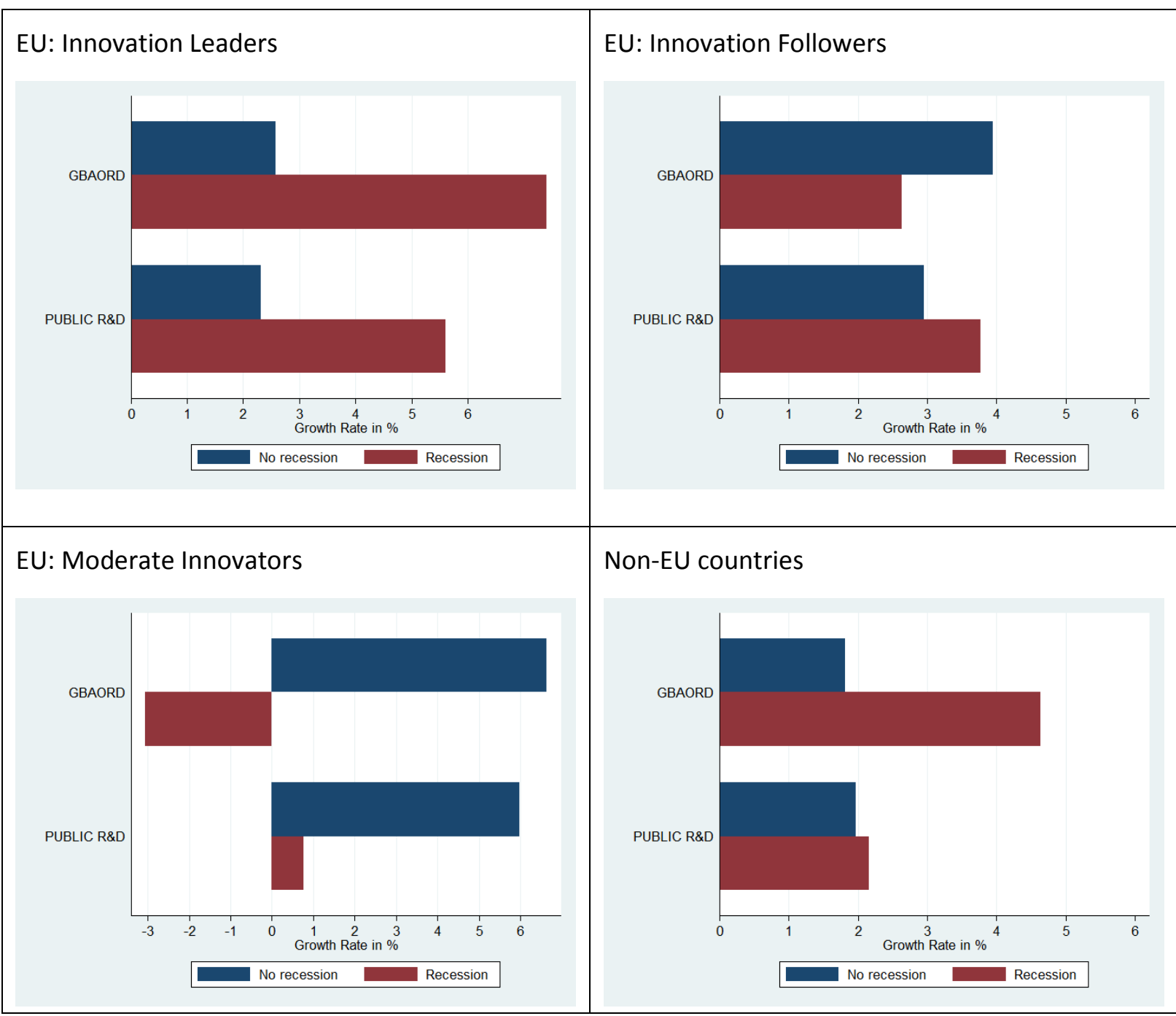

Note: A country's innovation performance is measured using the classification of the Innovation Union Scoreboard.

Figure 4 reveals intriguing country differences as response to economic crises. This probably reflects country-specific developments and strategies pursued. Innovation leaders like Germany, Denmark, Finland and Sweden show a strong counter-cyclical behaviour by fostering government financed R\&D to a much greater extent during recession periods. Whereas GBAORD increases on average by about 2.5 per cent during non-recession periods, it has grown on average by more than 8 per cent during recession periods. In contrast, we see a clear pro-cyclical behaviour of moderate innovators. Countries like the Czech Republic, Estonia, Greece, Hungary, Italy, Lithuania, Poland, Portugal, and Spain for example exhibit positive and high growth rates of government financed R\&D during non-recession periods. Consistent with a catching-up behaviour, these growth rates have even been higher than for innovation leaders. In recession periods, however, they substantially cut public budgets for R\&D. GBAORD, for instance, has decreased by about 3 percent. The growth rate of public R\&D expenditures

refrain from presenting results regarding the last group as the number of recession-affected periods is too small for inference in this case and both countries are dropped from the estimation due to missing information of other variables. 
is still positive but at a much lower value than in non-recession periods. Though the picture is ambiguous for innovation followers whether they behave pro- or counter-cyclical depending on the indicator, we can conclude that annual growth rates of GBAORD and Public R\&D only slightly differ over the business cycle. Although government financed R\&D is only one component of total R\&D expenditure, these figures in isolation support the view that the innovation gap between innovation leaders and moderate innovators in Europe has increased due to the most recent 2008 crisis.

For comparison, Figure 4 additionally depicts average annual growth rates of government financed R\&D for Non-European countries. We observe a similar counter-cyclical behaviour than for European innovation leaders though to a much lesser extent.

\subsection{Government Appropriations and Outlays for R\&D (GBAORD) by Thematic Areas}

The second part of the analysis investigates whether recessions affect the composition of the government R\&D budgets. When budgets change because of a recession, some elements might take priority over others. Therefore, we estimate the effect of the recession on the share of each component of GBAORD. We distinguish seven components, following the data availability in the MSTI database of the OECD: defence, health and environment, space, general university funds, economic development, education and social research, non-oriented R\&D.

Figure 5 shows the evolution of the average share of government budgets allocated to each spending category between 1981 and 2015 for the weighted total of 35 OECD countries. The data shows some clear trends. While the share of government budgets going to general university funds, education and social research, and economic development have been stable, economic development and defence $R \& D$ budgets have steadily declined throughout the years. In contrast, the share of government R\&D budgets and outlays assigned to non-oriented $R \& D$ and health and environment R\&D have gained in importance. The former has sharply increased from approximately $10 \%$ in the 1990 s to more than $20 \%$ in the 2010s; the latter has steadily increased to some 14\% of total GBAORD in 2015.

Figure 6 compares average GBAORD outlays in years marked as recessions to other years. As before, a recession year has been defined as a year in real GDP decreases. ${ }^{6}$ While some interesting patterns emerge, differences are limited to percentage point shifts in allocation. The largest difference is to be found in defence R\&D spending, which shifts from $9 \%$ in non-recession periods to $4 \%$ during recessions. The share of R\&D outlays for economic development also drops, though only slightly from $26 \%$ to $24 \%$. The share of space-oriented R\&D outlays remains stable, and the other categories receive a higher share of funding during a recession. While our analysis does not cover the causes of any such shifts, one explanation for these patterns could be that during recessions, private R\&D expenditures in these fields drop, and public funds are adjusted to compensate.

\footnotetext{
${ }^{6}$ A graph more generally separating upswing/boom periods and downturn/recession periods shows smaller differences than those obtained by separating out recessions.
} 
Figure 5: Evolution of GBAORD Components across Time

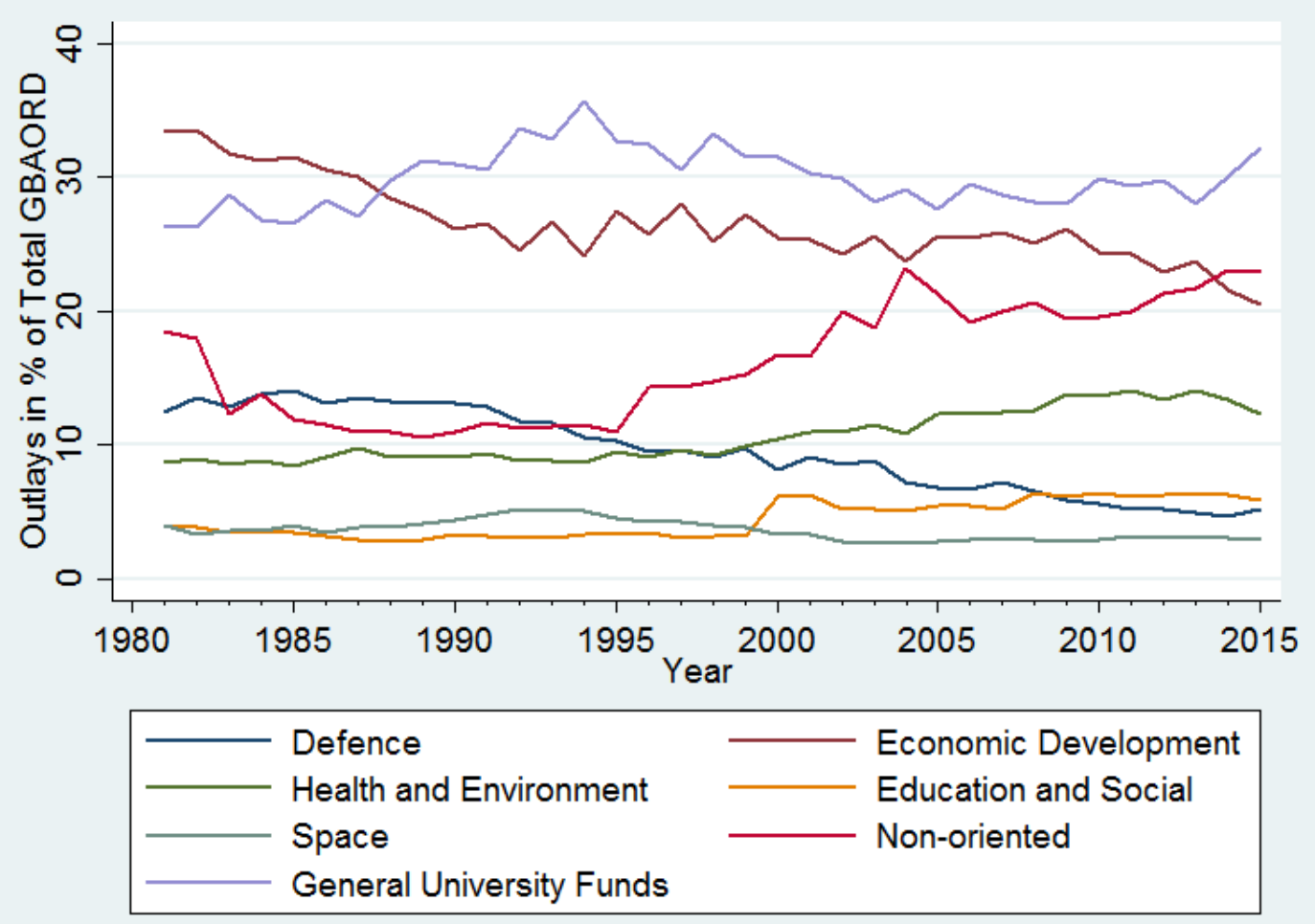

Note: Countries included: EU-28, Australia, Canada, Israel, Japan, Korea, Switzerland, and United States.

Figure 6: Composition of GBAORD Outlays in Recession versus Non-recession Periods

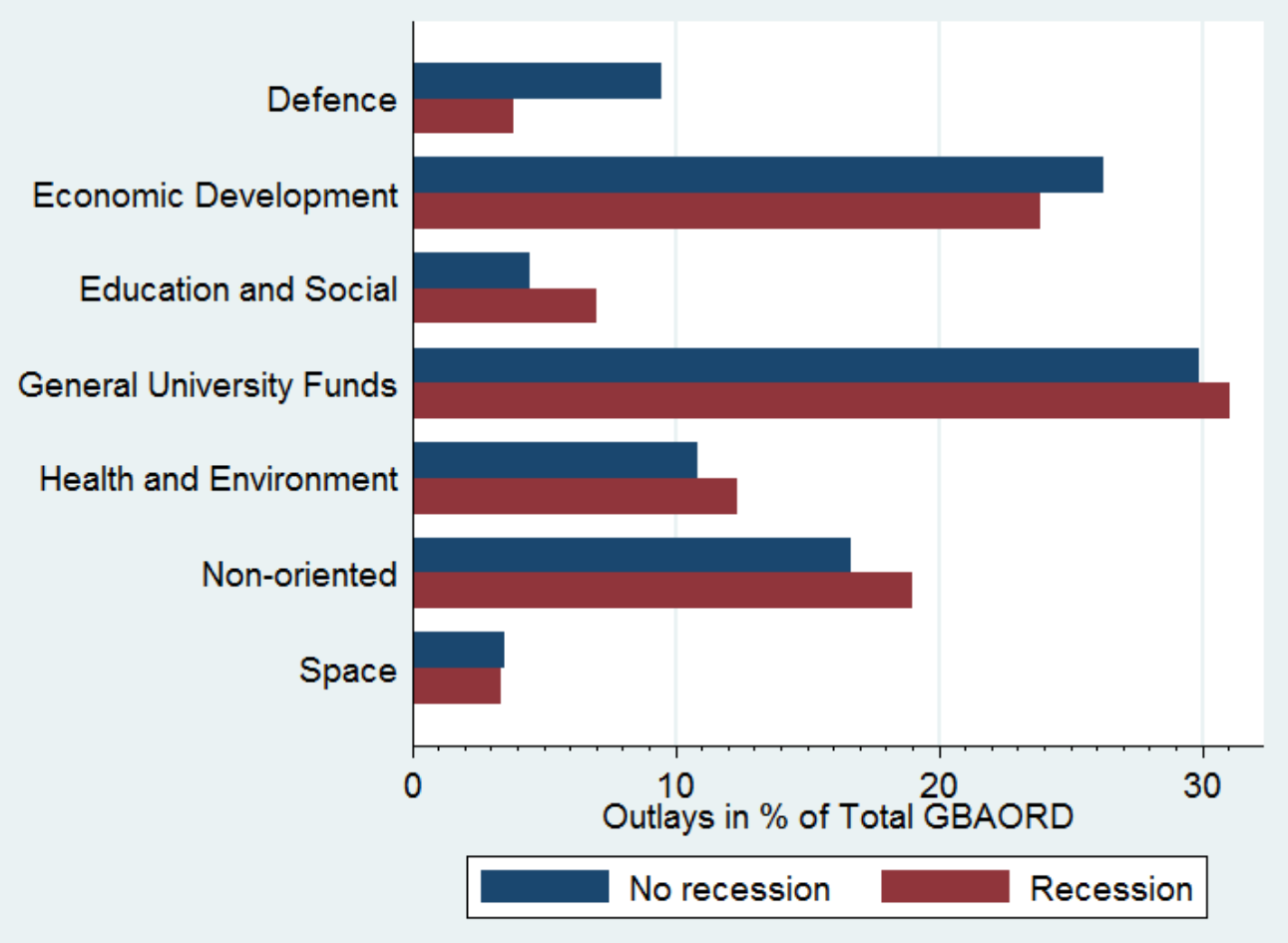

Note: Countries included: EU-28, Australia, Canada, Israel, Japan, Korea, Switzerland, and United States. 
Figure 7 presents the same data as in Figure 6, but split between two groups of countries: EU member states and Non-European OECD countries (Australia, Canada, Israel, Japan, Korea, Switzerland, and United States).. Note that among EU member states, the share of R\&D outlays for General University Funds was stable across recession and non-recession periods, and that the difference in the share of defence spending is larger among non-EU countries than for the EU.

Figure 7: Composition of GBAORD Outlays in Recession versus Non-recession Periods, EU versus Non-EU Countries

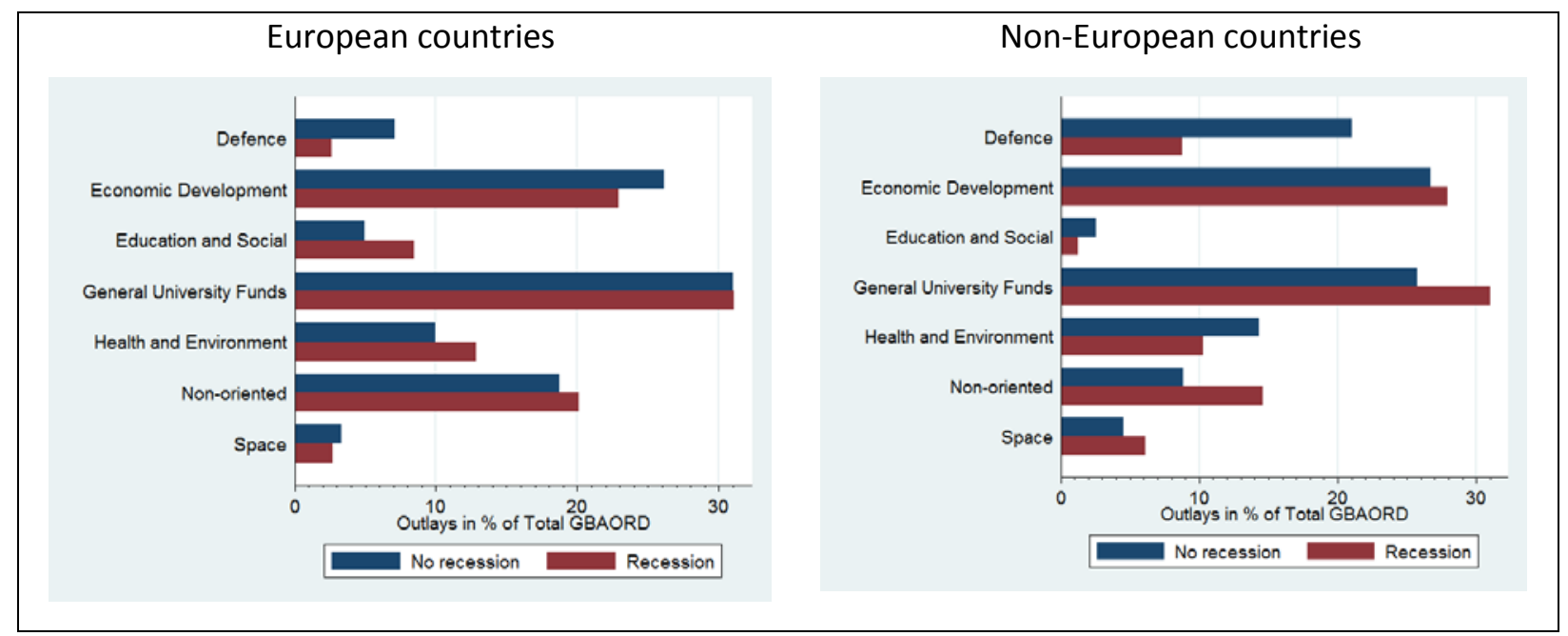

As public response to crises in terms of public R\&D expenditures might also depend on current innovative performance, we additionally present graphs by a country's ranking in the Innovation Union Scoreboard 2015 (European Commission, 2015). Figure 8 shows the results of this exercise for three groups of countries: Innovation Leaders, Innovation Followers, and Moderate Innovators. There are indeed marked differences among them, in that countries classified as Innovation Leaders the composition of GBAORD outlays is more stable across crises than countries classified as Innovation Followers or Moderate Innovators.

In the multivariate analyses (see section 5.2) we formalize these trends by estimating the share of GBAORD reserved for each category as a function of business cycle indicators (GDP growth and public surplus as share of GDP). Constant country-level heterogeneity will be accounted for through fixed effects. We additionally control for non-R\&D related government expenditures. For robustness we estimate the model using a dynamic panel approach (see Appendix).

The recession effect will be investigated in two ways. First, constant effects will be captured through the inclusion of a recession indicator variable. Second, differences in the surplus/R\&D spending relation will be captured through an interaction of this variable with public surplus. 
Figure 8: Composition of GBAORD Outlays in Recession versus Non-recession Periods, by Innovation Union Classification

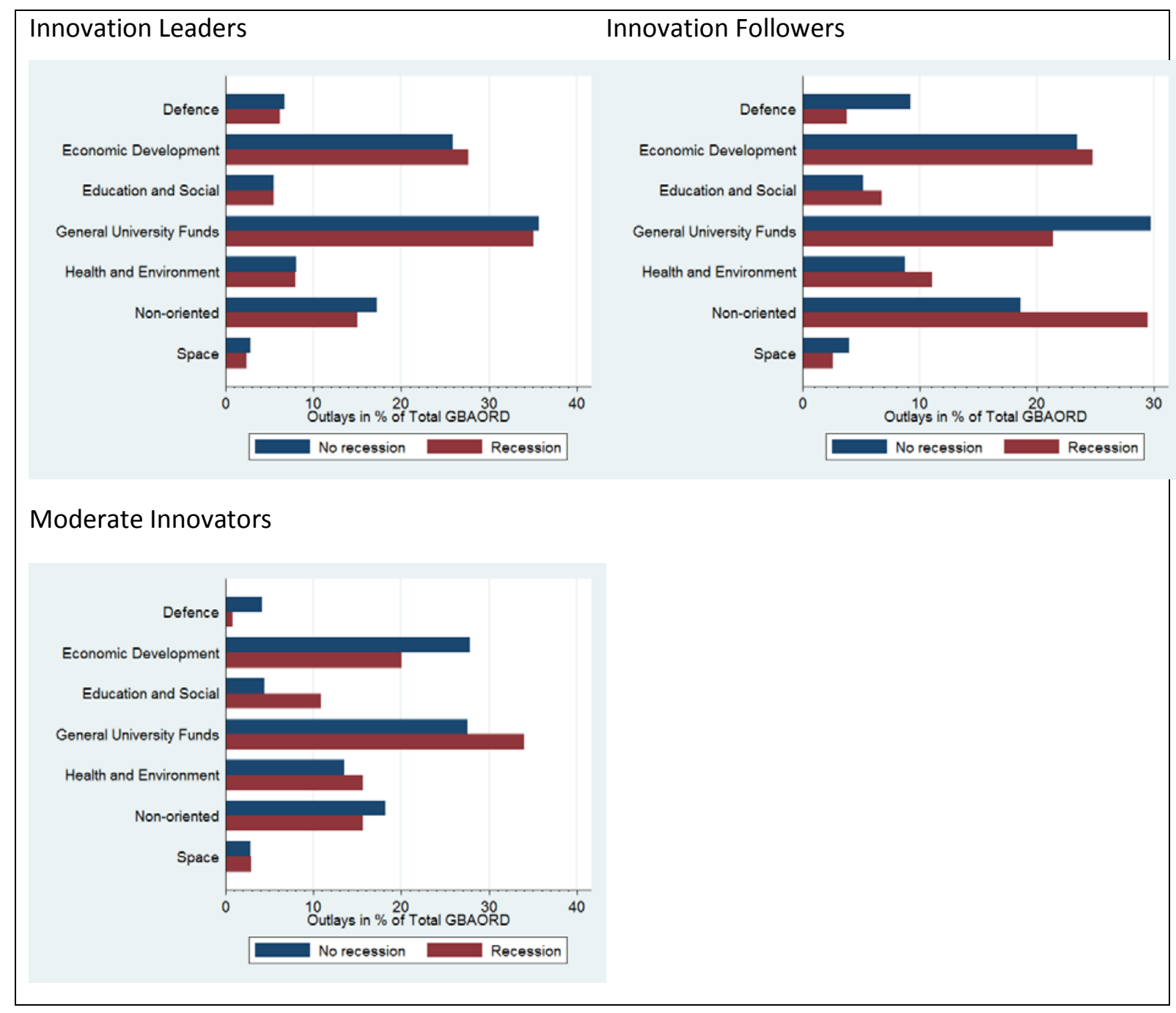

\subsection{Public R\&D Expenditures by Beneficiaries}

Not all government financed R\&D is performed by the government and its institutions. Hence, this last section presents the split of government financed R\&D expenditures by beneficiaries and its evolution over time. In 1995, about 47.7 percent of public R\&D was spent to finance expenditure on R\&D in the higher education sector (HERD). 15.2 percent of public R\&D was aimed at supporting R\&D performed in the business sector (BERD) and about 37.1 percent of public R\&D was devoted to government intramural R\&D activities (GOVERD). Figure 9 reveals a clear steady upward sloping trend for the share of government financed $R \& D$ that is devoted to higher education R\&D and a falling trend for the other two components of public R\&D over the last twenty years. In 2014, more than half of the public R\&D budget (57.9 percent) was spent on R\&D in the higher education sector, whereas intramural R\&D and business R\&D accounted for 30.5 and 11.6 percent, respectively. 
Figure 9: Evolution of Public R\&D Expenditures across Time, by Beneficiaries

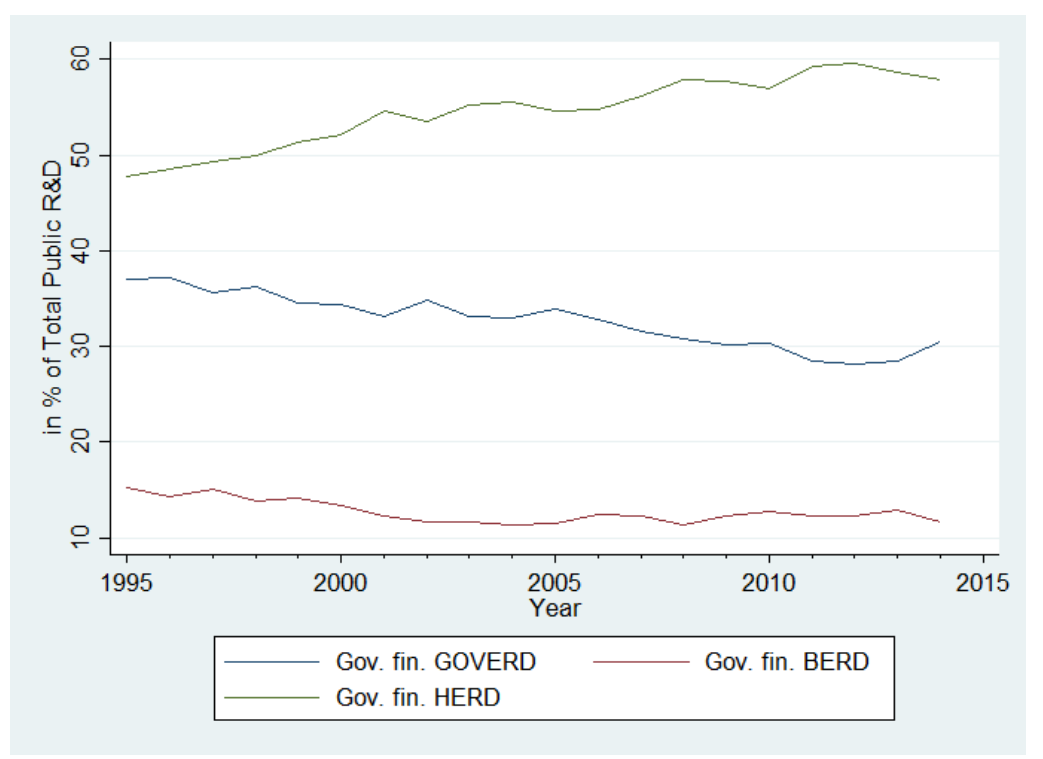

Note: Reported are the shares of government financed intramural R\&D (GOVERD), government financed business R\&D (BERD) and government financed higher education expenditure on R\&D (HERD), in total public R\&D (in \%)

\section{Empirical Results}

This section provides econometric evidence related to our research questions how the business cycle impacts public investments in R\&D and their components. Like the previous section, we structure the result section by first presenting evidence on how the business cycle impacts the level and growth of government financed R\&D in section 5.1. Section 5.2 and 5.3 provide results on the question whether and how the business cycle affects the composition of government financed R\&D with respect to thematic areas and to beneficiaries, respectively.

\subsection{Level and Growth of Government Financed R\&D Expenditure}

In order to investigate the impact of the business cycle on government financed R\&D expenditures in a multivariate analysis, we use model 1 as explained in section 3.2. Table 1 and Table 2 report the results for GBAORD and PubRD as dependent variable, respectively.

We start by estimating a dynamic baseline model for the whole sample including lagged GDP and lagged SURPLUS as additional explanatory variable. The estimates reveal high and significant state dependence in government financed R\&D expenditure. Even after accounting for unobserved countryspecific heterogeneity, the coefficient of the lagged dependent variable remains highly significant. The coefficient is always above 0.8 for GBAORD and it is even higher for PubRD. This implies that R\&D spending of the government sector is changing only gradually.

With respect to the impact of the business cycle, it turns out that lagged GDP is highly significant in the pooled OLS estimates (1) for both GBAORD and PubRD. This effect becomes even stronger when we additionally account for unobserved country heterogeneity in specification (2). It turns out that this effect is very robust to the different specifications (3) to (12). For GBAORD, the elasticity varies between 0.144 and 0.209 based on system GMM results. This implies that an increase in GDP by 1 
percent leads to a subsequent increase in GBAORD by roughly 0.15 to 0.2 percent on average. With a range of 0.079 to 0.172 this elasticity wrt to lagged GDP is slightly lower and somewhat less precisely estimated for PubRD . Overall, these findings corroborate a strong impact of business cycles on public $R \& D$ investments.

As already explained in section 3.2, lagged SURPLUS accounts for government's short-run financing conditions which may allow governments to pursue different R\&D strategies but it is also highly correlated with the business cycle. Results show an impressively robust impact of SURPLUS on GBAORD . An estimated coefficient of about 0.006 to 0.008 implies that all things equal an increase in the surplus to GDP ratio by 1 percentage point (or a reduction in the deficit to GDP ratio by 1 percentage point) increases GBAORD in the subsequent period by 0.6 to 0.8 percent. With an increase between 0.2 and 0.5 percent we find this effect again somewhat smaller and less precisely estimated for PubRD.

In order to account for long-run financing conditions, lagged $D E B T$ levels are introduced from specification (3) onwards which slightly reduces the sample size due to missing information for 2 countries. Whereas specification (3) does not account for unobserved country heterogeneity, it is controlled for specifications (4) and (5) using System GMM. The latter two specifications differ in their assumption about the correlation between lagged GDP, SURPLUS as well as DEBT and the idiosyncratic error term. There is a trade-off between allowing these variables to be endogenous (or predetermined) and getting an extremely high number of instruments as result or restricting them to be strictly exogenous which is associated with a much smaller set of instruments. As a comparison of specification (4) and (5) shows the results to be rather robust, so that we therefore decided to use the strict exogeneity assumption throughout the following estimations. Instrument validity cannot be rejected for all estimates using both the Hansen test on overidentifying restrictions and the test on lack of second order autocorrelation (AR2) by Arellano and Bond (1991). Hence specification (5) is our benchmark specification. It turns out that lagged DEBT is weakly significant in specification (5) and for most of the robustness checks. As expected, the coefficient is negative. This implies that increasing debt levels (in relation to GDP) forces governments to subsequently cut public R\&D spending. According to the estimates, an increase in the debt to GDP ratio by 1 percentage point lowers on average both GBAORD and PubRD by 0.03 percent.

Specifications (6) to (12) additionally account for business cycle effects by adding the 2-phases business cycle indicator RECESSION differentiating between recession and non-recession years. Compared to the quantitative GDP variable, the business cycle indicator performs much worse. RECESSION is not significant in any of the estimates for GBAORD and PubRD. In order to see whether the effects of our main explanatory variables differ in recession and non-recession years we additionally incorporate interaction terms. This allows us to answer e.g. the question whether governments' response to an increase (or decrease) in the budget surplus by 1 percentage point is different in a recession period compared to a non-recession period. Overall, there is not much evidence in favour of any interaction terms except for SURPLUS. Using the concurrent recession indicator, we find that an increase in the budget surplus by 1 percentage point raises GBAORD by roughly twice as much in recession periods (1.4 percent) compared to non-recession periods ( 0.6 percent). Long-term invest rates $I R$ which have been included to account for financing costs turn out to be insignificant throughout the estimates. 
Table 1: Model 1: Impact of Business Cycle Indicators on Government R\&D Expenditures (GBAORD)

\begin{tabular}{|c|c|c|c|c|c|c|c|c|c|c|c|c|}
\hline VARIABLES & $\begin{array}{c}(1) \\
\text { Pooled } \\
\text { OLS }\end{array}$ & $\begin{array}{c}(2) \\
\text { System } \\
\text { GMM }\end{array}$ & $\begin{array}{c}\text { (3) } \\
\text { Pooled } \\
\text { OLS }\end{array}$ & $\begin{array}{c}(4) \\
\text { System } \\
\text { GMM } \\
\text { endog. }\end{array}$ & $\begin{array}{c}\text { (5) } \\
\text { System } \\
\text { GMM } \\
\text { exog. }\end{array}$ & $\begin{array}{c}(6) \\
\text { System } \\
\text { GMM } \\
\text { exog. }\end{array}$ & $\begin{array}{c}\text { (7) } \\
\text { System } \\
\text { GMM } \\
\text { exog. }\end{array}$ & $\begin{array}{c}\text { (8) } \\
\text { Pooled } \\
\text { OLS } \\
\text { exog. }\end{array}$ & $\begin{array}{c}\text { (9) } \\
\text { System } \\
\text { GMM } \\
\text { exog. }\end{array}$ & $\begin{array}{l}(10) \\
\text { Pooled } \\
\text { OLS } \\
\text { exog. }\end{array}$ & $\begin{array}{c}(11) \\
\text { System } \\
\text { GMM } \\
\text { exog. }\end{array}$ & $\begin{array}{c}(12) \\
\text { System } \\
\text { GMM } \\
\text { exog. }\end{array}$ \\
\hline In GBAORD (t-1) & $\begin{array}{c}0.920^{* * *} \\
(0.013)\end{array}$ & $\begin{array}{c}0.869 * * * \\
(0.051)\end{array}$ & $\begin{array}{c}0.910 * * * \\
(0.017)\end{array}$ & $\begin{array}{c}0.889 * * * \\
(0.118)\end{array}$ & $\begin{array}{c}0.830 * * * \\
(0.067)\end{array}$ & $\begin{array}{c}0.993^{* * *} \\
(0.022)\end{array}$ & $\begin{array}{c}0.815^{* * *} \\
(0.075)\end{array}$ & $\begin{array}{c}0.914^{* * *} \\
(0.017)\end{array}$ & $\begin{array}{c}0.801 * * * \\
(0.153)\end{array}$ & $\begin{array}{c}0.913^{* * *} \\
(0.017)\end{array}$ & $\begin{array}{c}0.823^{* * *} \\
(0.081)\end{array}$ & $\begin{array}{c}0.809 * * * \\
(0.067)\end{array}$ \\
\hline $\ln G D P(\mathrm{t}-1)$ & $\begin{array}{c}0.080^{* * *} \\
(0.014)\end{array}$ & $\begin{array}{c}0.144^{* *} \\
(0.065)\end{array}$ & $\begin{array}{c}0.092^{* * *} \\
(0.020)\end{array}$ & $\begin{array}{c}0.170 \\
(0.177)\end{array}$ & $\begin{array}{c}0.181^{* * *} \\
(0.064)\end{array}$ & & $\begin{array}{c}0.202^{* *} \\
(0.079)\end{array}$ & $\begin{array}{c}0.087^{* * *} \\
(0.021)\end{array}$ & $\begin{array}{c}0.223 \\
(0.160)\end{array}$ & $\begin{array}{c}0.088^{* * *} \\
(0.020)\end{array}$ & $\begin{array}{c}0.201^{* *} \\
(0.087)\end{array}$ & $\begin{array}{r}0.209 * * * \\
(0.078)\end{array}$ \\
\hline SURPLUS (t-1) & $\begin{array}{c}0.007^{* * *} \\
(0.001)\end{array}$ & $\begin{array}{c}0.008^{* * *} \\
(0.002)\end{array}$ & $\begin{array}{c}0.006^{* * *} \\
(0.001)\end{array}$ & $\begin{array}{c}0.007^{* * *} \\
(0.003)\end{array}$ & $\begin{array}{c}0.006 * * * \\
(0.002)\end{array}$ & $\begin{array}{c}0.005^{* * *} \\
(0.002)\end{array}$ & $\begin{array}{c}0.006^{* * *} \\
(0.002)\end{array}$ & $\begin{array}{c}0.005^{* * *} \\
(0.001)\end{array}$ & $\begin{array}{c}0.007^{* *} \\
(0.003)\end{array}$ & $\begin{array}{c}0.005^{* * *} \\
(0.001)\end{array}$ & $\begin{array}{c}0.006^{* * *} \\
(0.002)\end{array}$ & $\begin{array}{c}0.006^{* * *} \\
(0.001)\end{array}$ \\
\hline$D E B T(\mathrm{t}-1)$ & & & $\begin{array}{c}-0.0002 \\
(0.0001)\end{array}$ & $\begin{array}{c}-0.0005 \\
(0.0004)\end{array}$ & $\begin{array}{c}-0.0003^{*} \\
(0.0002)\end{array}$ & $\begin{array}{l}-0.000 \\
(0.000)\end{array}$ & $\begin{array}{c}-0.0004^{* *} \\
(0.0002)\end{array}$ & $\begin{array}{c}-0.0002 \\
(0.0001)\end{array}$ & $\begin{array}{c}-0.0005 \\
(0.0004)\end{array}$ & $\begin{array}{c}-0.0002 * \\
(0.0001)\end{array}$ & $\begin{array}{c}-0.0004^{*} \\
(0.0002)\end{array}$ & $\begin{array}{l}-0.000 \\
(0.000)\end{array}$ \\
\hline$I R(\mathrm{t})$ & & & $\begin{array}{c}-0.002 \\
(0.002)\end{array}$ & $\begin{array}{l}-0.000 \\
(0.003)\end{array}$ & $\begin{array}{c}-0.004 \\
(0.004)\end{array}$ & $\begin{array}{c}0.001 \\
(0.005)\end{array}$ & $\begin{array}{c}-0.003 \\
(0.004)\end{array}$ & $\begin{array}{c}-0.002 \\
(0.002)\end{array}$ & $\begin{array}{c}-0.001 \\
(0.010)\end{array}$ & $\begin{array}{l}-0.002 \\
(0.002)\end{array}$ & $\begin{array}{c}-0.002 \\
(0.007)\end{array}$ & $\begin{array}{l}-0.002 \\
(0.004)\end{array}$ \\
\hline RECESSION (t-1) & & & & & & $\begin{array}{l}-0.018 \\
(0.024)\end{array}$ & $\begin{array}{c}0.002 \\
(0.015)\end{array}$ & $\begin{array}{l}-0.111 \\
(0.154)\end{array}$ & $\begin{array}{c}0.089 \\
(2.241)\end{array}$ & $\begin{array}{l}-0.054 \\
(0.034)\end{array}$ & $\begin{array}{l}-0.018 \\
(0.044)\end{array}$ & $\begin{array}{l}0.100^{*} \\
(0.058)\end{array}$ \\
\hline In GDP $\times$ RECESSION (t-1) & & & & & & & & $\begin{array}{c}0.005 \\
(0.012)\end{array}$ & $\begin{array}{l}-0.007 \\
(0.170)\end{array}$ & & & \\
\hline SURPLUS $\times$ RECESSION (t-1) & & & & & & & & $\begin{array}{c}0.000 \\
(0.004)\end{array}$ & $\begin{array}{l}-0.002 \\
(0.004)\end{array}$ & $\begin{array}{c}0.001 \\
(0.003)\end{array}$ & $\begin{array}{l}-0.003 \\
(0.004)\end{array}$ & $\begin{array}{l}0.008^{*} \\
(0.004)\end{array}$ \\
\hline$D E B T \times R E C E S S I O N(\mathrm{t}-1)$ & & & & & & & & $\begin{array}{l}0.0003^{*} \\
(0.0002)\end{array}$ & $\begin{array}{l}0.0001 \\
(0.002)\end{array}$ & $\begin{array}{c}0.0004^{* *} \\
(0.0001)\end{array}$ & $\begin{array}{c}0.0001 \\
(0.0003)\end{array}$ & $\begin{array}{l}-0.001 \\
(0.001)\end{array}$ \\
\hline IR $\times$ RECESSION $(\mathrm{t}-1)$ & & & & & & & & $\begin{array}{c}-0.000 \\
(0.005)\end{array}$ & $\begin{array}{l}-0.003 \\
(0.031)\end{array}$ & & & \\
\hline Constant & $\begin{array}{c}-0.358^{* * *} \\
(0.093) \\
\end{array}$ & $\begin{array}{c}-0.784^{*} \\
(0.464) \\
\end{array}$ & $\begin{array}{c}-0.421^{* * *} \\
(0.127) \\
\end{array}$ & $\begin{array}{l}-1.258 \\
(1.391) \\
\end{array}$ & $\begin{array}{c}-0.934 * * * \\
(0.325) \\
\end{array}$ & $\begin{array}{c}0.106 \\
(0.184) \\
\end{array}$ & $\begin{array}{c}-1.091^{* *} \\
(0.455) \\
\end{array}$ & $\begin{array}{c}-0.385^{* * *} \\
(0.127) \\
\end{array}$ & $\begin{array}{l}-1.254 \\
(1.031) \\
\end{array}$ & $\begin{array}{c}-0.391 * * * \\
(0.126) \\
\end{array}$ & $\begin{array}{c}-1.143^{*} \\
(0.633) \\
\end{array}$ & $\begin{array}{c}-1.147^{* *} \\
(0.554) \\
\end{array}$ \\
\hline R-squared & 0.997 & & 0.997 & & & & & 0.997 & & 0.997 & & \\
\hline J & . & 23.897 & . & 18.634 & 18.777 & 21.386 & 18.169 & . & 16.477 & . & 16.827 & 15.997 \\
\hline$J$ (p-value) & . & 1.000 & & 1.000 & 1.000 & 1.000 & 1.000 & . & 1.000 & . & 1.000 & 1.000 \\
\hline AR1 ( $p$-value) & . & 0.004 & . & 0.010 & 0.010 & 0.007 & 0.010 & & 0.018 & . & 0.009 & 0.007 \\
\hline AR2 (p-value) & . & 0.116 & $\cdot$ & 0.187 & 0.185 & 0.178 & 0.187 & $\cdot$ & 0.259 & & 0.175 & 0.200 \\
\hline Observations & 474 & 474 & 412 & 412 & 412 & 412 & 412 & 412 & 412 & 412 & 412 & 412 \\
\hline No. countries & 26 & 26 & 24 & 24 & 24 & 24 & 24 & 24 & 24 & 24 & 24 & 24 \\
\hline
\end{tabular}

Notes: $* * * p<0.01, * * p<0.05, * p<0.1$. Clustered standard errors in parentheses for pooled OLS and Windmijer finite-sample corrected standard errors for System GMM. Estonia and South Korea are dropped due to missing information from estimation (3) onwards. (12) uses current recession indicator. 
Table 2: Model 1: Impact of Business Cycle Indicators on Government R\&D Expenditures (PubRD)

\begin{tabular}{|c|c|c|c|c|c|c|c|c|c|c|c|c|}
\hline VARIABLES & $\begin{array}{l}\text { (1) } \\
\text { Pooled } \\
\text { OLS }\end{array}$ & $\begin{array}{c}\text { (2) } \\
\text { System } \\
\text { GMM }\end{array}$ & $\begin{array}{l}\text { (3) } \\
\text { Pooled } \\
\text { OLS }\end{array}$ & $\begin{array}{c}\text { (4) } \\
\text { System } \\
\text { GMM } \\
\text { endog. }\end{array}$ & $\begin{array}{c}(5) \\
\text { System } \\
\text { GMM } \\
\text { exog. }\end{array}$ & $\begin{array}{c}(6) \\
\text { System } \\
\text { GMM } \\
\text { exog. }\end{array}$ & $\begin{array}{c}\text { (7) } \\
\text { System } \\
\text { GMM } \\
\text { exog. }\end{array}$ & $\begin{array}{c}(8) \\
\text { Pooled } \\
\text { OLS } \\
\text { exog. }\end{array}$ & $\begin{array}{c}\text { (9) } \\
\text { System } \\
\text { GMM } \\
\text { exog. }\end{array}$ & $\begin{array}{c}(10) \\
\text { Pooled } \\
\text { OLS } \\
\text { exog. }\end{array}$ & $\begin{array}{c}(11) \\
\text { System } \\
\text { GMM } \\
\text { exog. }\end{array}$ & $\begin{array}{c}(12) \\
\text { System } \\
\text { GMM } \\
\text { exog. }\end{array}$ \\
\hline $\ln G B A O R D(\mathrm{t}-1)$ & $\begin{array}{c}0.927 * * * \\
(0.011)\end{array}$ & $\begin{array}{c}0.928^{* * *} \\
(0.030)\end{array}$ & $\begin{array}{c}0.918^{* * *} \\
(0.011)\end{array}$ & $\begin{array}{c}0.985^{* * *} \\
(0.066)\end{array}$ & $\begin{array}{c}0.891^{* * *} \\
(0.049)\end{array}$ & $\begin{array}{c}1.006^{* * *} \\
(0.027)\end{array}$ & $\begin{array}{c}0.890^{* * *} \\
(0.056)\end{array}$ & $\begin{array}{c}0.919 * * * \\
(0.011)\end{array}$ & $\begin{array}{c}0.850^{* * *} \\
(0.123)\end{array}$ & $\begin{array}{c}0.920^{* * *} \\
(0.011)\end{array}$ & $\begin{array}{c}0.961^{* * *} \\
(0.073)\end{array}$ & $\begin{array}{c}0.639 * * * \\
(0.182)\end{array}$ \\
\hline $\ln G D P(\mathrm{t}-1)$ & $\begin{array}{c}0.072 * * * \\
(0.013)\end{array}$ & $\begin{array}{c}0.079 * * \\
(0.034)\end{array}$ & $\begin{array}{c}0.081 * * * \\
(0.011)\end{array}$ & $\begin{array}{c}0.029 \\
(0.077)\end{array}$ & $\begin{array}{c}0.112^{* *} \\
(0.048)\end{array}$ & & $\begin{array}{c}0.113^{* *} \\
(0.056)\end{array}$ & $\begin{array}{c}0.080 * * * \\
(0.011)\end{array}$ & $\begin{array}{c}0.172 \\
(0.125)\end{array}$ & $\begin{array}{c}0.079 * * * \\
(0.012)\end{array}$ & $\begin{array}{c}0.068 \\
(0.070)\end{array}$ & $\begin{array}{l}0.415^{*} \\
(0.241)\end{array}$ \\
\hline SURPLUS (t-1) & $\begin{array}{c}0.006 * * * \\
(0.001)\end{array}$ & $\begin{array}{c}0.005^{* * * *} \\
(0.002)\end{array}$ & $\begin{array}{c}0.004^{* * *} \\
(0.001)\end{array}$ & $\begin{array}{c}0.004 \\
(0.002)\end{array}$ & $\begin{array}{c}0.003 \\
(0.002)\end{array}$ & $\begin{array}{c}0.002 \\
(0.002)\end{array}$ & $\begin{array}{c}0.003 \\
(0.002)\end{array}$ & $\begin{array}{c}0.004^{* * *} \\
(0.001)\end{array}$ & $\begin{array}{c}0.002 \\
(0.002)\end{array}$ & $\begin{array}{c}0.004^{* * *} \\
(0.001)\end{array}$ & $\begin{array}{l}0.003^{*} \\
(0.002)\end{array}$ & $\begin{array}{c}0.003 \\
(0.002)\end{array}$ \\
\hline$D E B T(\mathrm{t}-1)$ & & & $\begin{array}{l}-0.0001 \\
(0.0001)\end{array}$ & $\begin{array}{l}-0.001 \\
(0.001)\end{array}$ & $\begin{array}{c}-0.0003^{*} \\
(0.0001)\end{array}$ & $\begin{array}{l}-0.001 \\
(0.001)\end{array}$ & $\begin{array}{c}-0.000^{*} \\
(0.000)\end{array}$ & $\begin{array}{c}-0.000^{*} \\
(0.000)\end{array}$ & $\begin{array}{c}-0.000 * * * \\
(0.000)\end{array}$ & $\begin{array}{c}-0.000^{*} \\
(0.000)\end{array}$ & $\begin{array}{c}-0.000^{* * *} \\
(0.000)\end{array}$ & $\begin{array}{l}-0.000 \\
(0.000)\end{array}$ \\
\hline$I R(\mathrm{t})$ & & & $\begin{array}{c}-0.004^{* *} \\
(0.002)\end{array}$ & $\begin{array}{l}-0.003 \\
(0.006)\end{array}$ & $\begin{array}{l}-0.007 \\
(0.004)\end{array}$ & $\begin{array}{l}-0.008 \\
(0.005)\end{array}$ & $\begin{array}{l}-0.007 \\
(0.004)\end{array}$ & $\begin{array}{c}-0.005^{* *} \\
(0.002)\end{array}$ & $\begin{array}{l}-0.007 \\
(0.011)\end{array}$ & $\begin{array}{c}-0.004^{* *} \\
(0.002)\end{array}$ & $\begin{array}{c}0.004 \\
(0.008)\end{array}$ & $\begin{array}{l}-0.005 \\
(0.007)\end{array}$ \\
\hline RECESSION (t-1) & & & & & & $\begin{array}{l}-0.013 \\
(0.016)\end{array}$ & $\begin{array}{c}0.002 \\
(0.020)\end{array}$ & $\begin{array}{c}-0.015 \\
(0.137)\end{array}$ & $\begin{array}{l}-1.158 \\
(0.781)\end{array}$ & $\begin{array}{c}-0.028 \\
(0.036)\end{array}$ & $\begin{array}{l}-0.035 \\
(0.051)\end{array}$ & $\begin{array}{l}-0.049 \\
(0.083)\end{array}$ \\
\hline In GDP $\times$ RECESSION (t-1) & & & & & & & & $\begin{array}{l}-0.002 \\
(0.011)\end{array}$ & $\begin{array}{c}0.081 \\
(0.059)\end{array}$ & & & \\
\hline SURPLUS $\times$ RECESSION (t-1) & & & & & & & & $\begin{array}{c}0.000 \\
(0.003)\end{array}$ & $\begin{array}{l}-0.001 \\
(0.003)\end{array}$ & $\begin{array}{l}-0.000 \\
(0.003)\end{array}$ & $\begin{array}{l}-0.002 \\
(0.003)\end{array}$ & $\begin{array}{c}0.001 \\
(0.004)\end{array}$ \\
\hline$D E B T \times R E C E S S I O N(\mathrm{t}-1)$ & & & & & & & & $\begin{array}{c}0.000 \\
(0.000)\end{array}$ & $\begin{array}{l}-0.000 \\
(0.001)\end{array}$ & $\begin{array}{c}0.000 \\
(0.000)\end{array}$ & $\begin{array}{c}0.000 \\
(0.000)\end{array}$ & $\begin{array}{c}0.000 \\
(0.001)\end{array}$ \\
\hline$I R \times R E C E S S I O N(\mathrm{t}-1)$ & & & & & & & & $\begin{array}{c}0.003 \\
(0.004)\end{array}$ & $\begin{array}{c}0.018 \\
(0.015)\end{array}$ & & & \\
\hline Constant & $\begin{array}{c}-0.310^{* * *} \\
(0.081)\end{array}$ & $\begin{array}{l}-0.398 \\
(0.280)\end{array}$ & $\begin{array}{c}-0.324^{* * *} \\
(0.071)\end{array}$ & $\begin{array}{l}-0.158 \\
(0.680)\end{array}$ & $\begin{array}{c}-0.490^{*} \\
(0.268)\end{array}$ & $\begin{array}{c}0.104 \\
(0.187)\end{array}$ & $\begin{array}{l}-0.493 \\
(0.316)\end{array}$ & $\begin{array}{c}-0.308^{* * *} \\
(0.068)\end{array}$ & $\begin{array}{l}-0.958 \\
(0.675)\end{array}$ & $\begin{array}{c}-0.308^{* * *} \\
(0.073)\end{array}$ & $\begin{array}{l}-0.536 \\
(0.427)\end{array}$ & $\begin{array}{l}-2.450 \\
(1.719)\end{array}$ \\
\hline R-squared & 0.999 & & 0.999 & & & & & 0.999 & & 0.999 & & \\
\hline J & . & 20.980 & . & 16.542 & 15.193 & 14.541 & 15.199 & . & 7.805 & . & 10.876 & 10.866 \\
\hline $\mathrm{p}$-value & . & 1.000 & . & 1.000 & 1.000 & 1.000 & 1.000 & . & 1.000 & . & 1.000 & 1.000 \\
\hline AR1 (p-value) & $\cdot$ & 0.007 & . & 0.001 & 0.002 & 0.002 & 0.002 & . & 0.000 & . & 0.001 & 0.060 \\
\hline AR2 (p-value) & $\cdot$ & 0.942 & . & 0.771 & 0.826 & 0.851 & 0.839 & . & 0.221 & . & 0.782 & 0.771 \\
\hline Observations & 354 & 354 & 286 & 286 & 286 & 286 & 286 & 286 & 286 & 286 & 286 & 286 \\
\hline No. of countries & 23 & 23 & 21 & 21 & 21 & 21 & 21 & 21 & 21 & 21 & 21 & 21 \\
\hline
\end{tabular}

Notes: $* * * p<0.01, * * p<0.05, * p<0.1$. Clustered standard errors in parentheses for pooled OLS and Windmijer finite-sample corrected standard errors for System GMM. Estonia and South Korea are dropped due to missing information from estimation (3) onwards. 
Table A.1 in the Appendix presents some additional robustness checks for model 1 using the 4-phases business cycle indicators BOOM, DOWNTURN and RECESSION and the GDP growth rate as explanatory variables for business cycle variations. Again, it turns out that these indicators perform worth in the estimation while the results on the other variables are rather robust to this change in specification. Finally, Table A.1 also includes dummy indicators for innovation followers, moderate innovators and non-EU countries (with innovation leaders being the reference group). None of these country group dummies indicating innovation performance turns out to be significant for the level of $R \& D$ expenditure financed by the government sector.

Instead of using the level of government financed R\&D, model 2 uses the corresponding growth rate as dependent variable (see section 3.2). Table 3 reports the estimation results for both GRGBAORD and GRPubRD. Results for SURPLUS and DEBT are pretty much in line with the results for model 1. The coefficient of SURPLUS is highly significant and indicates that an increase in the budget surplus in relation to GDP by 1 percentage point stimulates growth of GBAORD by 0.6 to 0.8 percentage points. With an increase between 0.4 and 0.5 percentage points this effect is again somewhat smaller and less precisely estimated for PubRD. The effect of $D E B T$ is also in a similar range but less significant than in model 1 . In contrast to the results for model 1 , we do not find a significant effect of the GDP growth rate. Instead we find the RECESSION indicator significant in most of the estimates for GRGBAORD and partly also for GRPubRD. On average, the growth of GBAORD is 2.5 percentage points lower in recessions than in non-recession periods. Most interestingly, we corroborate the descriptive finding that European innovation leaders follow a counter-cyclical behaviour also in the multivariate analysis. All others things equal, growth of GBAORD is about 2.876 percentage points higher in recession periods than in non-recession periods for innovation leaders. As there is no significant difference with respect to non-EU countries, we can conclude that counter-cyclicality also holds for them. In contrast, we find pro-cyclicality for innovation followers and moderate innovators. For both country groups the interaction term with RECESSION is highly significant. Based on the estimates, growth of GBAORD is about 1.706 and 8.575 percentage points lower for innovation followers and moderate innovators, respectively. Results for public R\&D expenditures ( PubRD) are somewhat weaker but they also confirm counter-cyclical behaviour for innovation leaders and procyclicality for moderate innovators. 
Table 3: Model 2: Impact of Business Cycle Indicators on the Growth of Government R\&D Expenditures (GBAORD and PubRD)

\begin{tabular}{|c|c|c|c|c|c|c|c|c|c|c|}
\hline & \multicolumn{5}{|c|}{ GBAORD } & \multicolumn{5}{|c|}{ PubRD } \\
\hline & (1) & (2) & (3) & (4) & (5) & $(6)$ & (7) & $(8)$ & (9) & (10) \\
\hline \multirow[t]{2}{*}{$G R G D P(\mathrm{t}-1)$} & -0.459 & & & -0.258 & -0.226 & $0.316^{*}$ & & & 0.097 & 0.182 \\
\hline & $(0.404)$ & & & $(0.214)$ & (0.219) & $(0.182)$ & & & (0.129) & $(0.123)$ \\
\hline \multirow[t]{2}{*}{ SURPLUS (t-1) } & $0.655^{* * *}$ & $0.745^{* * *}$ & $0.732 * * *$ & $0.693 * * *$ & $0.802 * * *$ & $0.447^{* *}$ & $0.531 * * *$ & $0.534 * * *$ & $0.410^{* *}$ & $0.461^{* *}$ \\
\hline & $(0.155)$ & $(0.135)$ & $(0.130)$ & $(0.145)$ & $(0.162)$ & $(0.196)$ & $(0.166)$ & $(0.173)$ & $(0.158)$ & $(0.170)$ \\
\hline \multirow[t]{2}{*}{$D E B T(\mathrm{t}-1)$} & -0.024 & $-0.049 * *$ & $-0.046 * *$ & $-0.050 * *$ & $-0.035^{*}$ & 0.006 & -0.031 & -0.033 & -0.032 & -0.026 \\
\hline & $(0.022)$ & (0.018) & $(0.018)$ & $(0.022)$ & (0.019) & $(0.022)$ & $(0.022)$ & $(0.022)$ & $(0.023)$ & $(0.023)$ \\
\hline \multirow[t]{2}{*}{$I R(\mathrm{t})$} & $-0.605^{*}$ & 0.239 & 0.233 & $0.421^{*}$ & $0.456 * *$ & $-1.036^{* * *}$ & $-0.525^{* *}$ & $-0.517 * *$ & $-0.419 * *$ & $-0.481 * *$ \\
\hline & $(0.308)$ & (0.178) & (0.171) & $(0.220)$ & $(0.175)$ & (0.309) & $(0.202)$ & (0.201) & (0.184) & (0.178) \\
\hline \multirow[t]{2}{*}{ BOOM (t-1) } & & $-1.929^{*}$ & & & & & -0.121 & & & \\
\hline & & (1.065) & & & & & $(0.775)$ & & & \\
\hline \multirow[t]{2}{*}{ DOWNTURN (t-1) } & & -1.452 & & & & & $1.208^{*}$ & & & \\
\hline & & $(0.966)$ & & & & & $(0.602)$ & & & \\
\hline \multirow[t]{2}{*}{ RECESSION $(\mathrm{t}-1)$} & & $-3.420 * *$ & $-2.521 *$ & -0.444 & $2.876^{* *}$ & & -0.482 & -1.076 & 0.161 & $1.716^{* *}$ \\
\hline & & $(1.506)$ & $(1.434)$ & (3.954) & $(1.161)$ & & (1.015) & (0.975) & $(2.072)$ & $(0.773)$ \\
\hline \multirow[t]{2}{*}{ GRGDP $\times$ RECESSION (t-1) } & & & & 0.136 & & & & & 0.444 & \\
\hline & & & & $(0.650)$ & & & & & $(0.258)$ & \\
\hline \multirow[t]{2}{*}{ SURPLUS $\times$ RECESSION (t-1) } & & & & 0.919 & & & & & $0.478^{*}$ & \\
\hline & & & & $(0.550)$ & & & & & $(0.244)$ & \\
\hline \multirow[t]{2}{*}{$D E B T \times R E C E S S I O N(\mathrm{t}-1)$} & & & & 0.013 & & & & & -0.002 & \\
\hline & & & & $(0.025)$ & & & & & $(0.014)$ & \\
\hline \multirow[t]{2}{*}{ RECESSION $(\mathrm{t}-1) \times$ FOLLOWER } & & & & & $-4.582 * *$ & & & & & -1.020 \\
\hline & & & & & $(2.039)$ & & & & & $(1.196)$ \\
\hline \multirow[t]{2}{*}{ RECESSION (t-1) x MODERATE } & & & & & $-11.451 * * *$ & & & & & $-4.845^{* *}$ \\
\hline & & & & & $(2.156)$ & & & & & $(2.133)$ \\
\hline \multirow[t]{2}{*}{ RECESSION (t-1) X NON-EU } & & & & & 0.010 & & & & & -1.553 \\
\hline & & & & & $(2.636)$ & & & & & $(1.194)$ \\
\hline \multirow[t]{2}{*}{ Constant } & $7.293 * * *$ & $9.378 * * *$ & $8.188 * * *$ & $8.827^{* * *}$ & $7.595 * * *$ & -0.138 & $9.740 * * *$ & $10.470 * * *$ & $9.151 * * *$ & $8.634 * * *$ \\
\hline & $(2.201)$ & $(1.296)$ & $(1.499)$ & $(2.098)$ & $(1.654)$ & (2.608) & $(1.736)$ & $(1.796)$ & $(2.123)$ & $(2.104)$ \\
\hline Time Dummies & Yes & No & No & No & No & Yes & No & No & No & No \\
\hline R-squared & 0.145 & 0.105 & 0.099 & 0.118 & 0.122 & 0.214 & 0.144 & 0.136 & 0.161 & 0.149 \\
\hline rho & 0.171 & 0.150 & 0.149 & 0.172 & 0.162 & 0.428 & 0.291 & 0.290 & 0.370 & 0.322 \\
\hline Observations & 412 & 412 & 412 & 412 & 412 & 286 & 286 & 286 & 286 & 286 \\
\hline Number of countries & 24 & 24 & 24 & 24 & 24 & 21 & 21 & 21 & 21 & 21 \\
\hline
\end{tabular}

Notes: Fixed effects (FE) estimates. Clustered standard errors in parentheses. ${ }^{* * *} p<0.01,{ }^{* *} p<0.05, * p<0.1$. 


\subsection{Government Appropriations and Outlays for R\&D (GBAORD) by Thematic Areas}

Table 4 presents the estimation results of the fixed effects specification for the seven components of GBAORD and for total civil R\&D (i.e. total GBAORD minus defence R\&D outlays). As main explanatory variables we include the lagged growth rate of GDP, the lagged to budget surplus to GDP ratio and the ratio of total non-R\&D government expenditure to GDP. Columns 1 and 2 represent estimates of the shares of defence and total civil spending in total GBAORD. Columns 3 through 8 present estimates of the share of the components of civil spending as a share of total civil GBAORD. Note that specifications 1 and 2 do not include data from Israel, for which no defence spending was available, and that specification 8 does not include data from South Korea, for which no university funds spending was reported.

Neither defence-related GBAORD nor GBAORD assigned to civil topics vary systematically along GDP growth, public surplus, or general government expenditures. This holds for the components of civil GBAORD too. Even though column 5 shows a positive relation between education and social GBAORD and public surplus, and column 6 shows a negative relation between GDP growth and space-related GBAORD, both effects are small (less than one percentage point). The latter relation is also not supported by the results of the dynamic panel specification (see Appendix). The effect of public surplus on education and social research is supported by the dynamic panel specification, though the coefficient shrinks to $0.4 \%$ in that specification.

Next we turn to the differences in the composition of GBAORD during recession years. Table 5 presents the estimation results. While Figure 2 showed some differences in the composition of GBAORD during recession years, these largely fade when controlling for GDP growth, public surplus, and other government expenditures. The coefficient of the recession indicator is estimated at 1.5 percentage points at most, and is statistically insignificant from zero across all categories at $p>0.10$. Thus, the composition of GBAORD is not significantly affected by recessions.

The models in Table 5 also include an interaction between the recession indicator and public surplus. ${ }^{7}$ This accounts for the possibility that during a recession, some categories of GBAORD are funded with priority when more money becomes available. The nonsignificant and small coefficients - on the order of one percentage point or less - show that this is largely not the case. Only the coefficient of R\&D outlays for economic development is weakly statistically significant $(p<0.10)$, and leads to the interpretation that during a recession, a one percentage point increase in the public surplus to GDP ratio leads to a 0.28 percentage point more increase in economic development $R \& D$ outlays than would have happened if there had not been a recession.

\footnotetext{
${ }^{7}$ The results discussed above remain robust to omitting this interaction from the model.
} 
Table 4: Model 3: FE regression of composition of GBAORD: base specification

\begin{tabular}{|c|c|c|c|c|c|c|c|c|}
\hline & (1) & $(2)$ & (3) & (4) & (5) & (6) & (7) & (8) \\
\hline VARIABLES & Defence & Civil GBAORD & Economic Development & Health \& Environment & Education \& Social & Space & Non-oriented & University Funds \\
\hline \multirow[t]{2}{*}{ GRGDP (t-1) } & -0.127 & 0.127 & 0.295 & -0.037 & -0.201 & $-0.085^{* *}$ & 0.094 & -0.093 \\
\hline & $(0.151)$ & $(0.151)$ & $(0.210)$ & $(0.105)$ & $(0.143)$ & $(0.038)$ & $(0.262)$ & $(0.122)$ \\
\hline \multirow[t]{2}{*}{ SURPLUS (t-1) } & -0.037 & 0.037 & 0.056 & -0.103 & $0.181^{* *}$ & 0.048 & -0.239 & 0.063 \\
\hline & $(0.092)$ & $(0.092)$ & $(0.117)$ & $(0.093)$ & $(0.068)$ & $(0.053)$ & $(0.188)$ & $(0.121)$ \\
\hline \multirow[t]{2}{*}{ GOVEXP $(\mathrm{t})$} & -0.231 & 0.231 & 0.022 & -0.007 & 0.121 & -0.040 & 0.109 & -0.215 \\
\hline & $(0.165)$ & $(0.165)$ & $(0.170)$ & $(0.106)$ & (0.129) & $(0.033)$ & $(0.209)$ & $(0.131)$ \\
\hline \multirow[t]{2}{*}{ Constant } & $20.085^{* *}$ & $79.915^{* * *}$ & $25.242 * * *$ & $11.724^{* *}$ & 1.114 & $7.455^{* * *}$ & 12.195 & $43.147^{* * *}$ \\
\hline & $(8.518)$ & $(8.518)$ & $(8.055)$ & $(5.320)$ & $(5.502)$ & $(1.976)$ & (9.974) & (6.188) \\
\hline Observations & 435 & 435 & 453 & 453 & 451 & 452 & 452 & 437 \\
\hline R-squared & 0.160 & 0.160 & 0.120 & 0.152 & 0.079 & 0.179 & 0.051 & 0.064 \\
\hline Number of countries & 26 & 26 & 27 & 27 & 27 & 27 & 27 & 26 \\
\hline sigma & 18.358 & 18.358 & 18.358 & 18.358 & 18.358 & 18.358 & 18.358 & 18.358 \\
\hline
\end{tabular}

Notes: Heteroskedasticity-robust standard errors in parentheses. $* * * p<0.01, * * p<0.05, *<p 0.1$. The dependent variables are the components of GBAORD as percentage of Total GBAORD for Defence and Civil GBAORD, and as a percentage of Civil GBAORD for the rest. Data: 1995-2015. 
Table 5: Model 3: FE regression of composition of GBAORD: interaction with recession indicator

\begin{tabular}{|c|c|c|c|c|c|c|c|c|}
\hline VARIABLES & $\begin{array}{c}(1) \\
\text { Defence }\end{array}$ & $\begin{array}{c}(2) \\
\text { Civil GBAORD }\end{array}$ & $\begin{array}{c}\text { (3) } \\
\text { Economic Development }\end{array}$ & $\begin{array}{c}\text { (4) } \\
\text { Health \& Environment }\end{array}$ & $\begin{array}{c}(5) \\
\text { Education \& Social }\end{array}$ & $\begin{array}{c}(6) \\
\text { Space }\end{array}$ & $\begin{array}{c}(7) \\
\text { Non-oriented }\end{array}$ & $\begin{array}{c}\text { (8) } \\
\text { University Funds }\end{array}$ \\
\hline \multirow[t]{2}{*}{ GRGDP (t-1) } & -0.163 & 0.163 & 0.267 & -0.038 & -0.132 & $-0.092 * *$ & 0.083 & -0.097 \\
\hline & $(0.126)$ & $(0.126)$ & $(0.226)$ & $(0.119)$ & $(0.116)$ & $(0.037)$ & $(0.301)$ & $(0.127)$ \\
\hline \multirow[t]{2}{*}{ RECESSION } & -0.464 & 0.464 & 0.941 & 1.005 & -0.307 & -0.518 & -1.147 & 0.448 \\
\hline & $(0.696)$ & $(0.696)$ & $(1.218)$ & $(0.837)$ & $(1.412)$ & $(0.366)$ & $(1.893)$ & $(1.318)$ \\
\hline \multirow[t]{2}{*}{ SURPLUS (t-1)) } & -0.040 & 0.040 & 0.028 & -0.122 & $0.210 * *$ & 0.056 & -0.221 & 0.053 \\
\hline & (0.095) & $(0.095)$ & $(0.113)$ & $(0.104)$ & $(0.097)$ & $(0.053)$ & $(0.196)$ & $(0.134)$ \\
\hline \multirow{2}{*}{$\begin{array}{l}\text { RECESSION } \mathrm{x} \\
\text { SURPLUS (t-1) }\end{array}$} & 0.089 & -0.089 & $0.275^{*}$ & 0.161 & -0.365 & -0.049 & -0.128 & 0.084 \\
\hline & $(0.185)$ & $(0.185)$ & $(0.145)$ & (0.139) & $(0.236)$ & $(0.046)$ & $(0.247)$ & $(0.131)$ \\
\hline \multirow[t]{2}{*}{ GOVEXP $(\mathrm{t})$} & -0.209 & 0.209 & 0.041 & -0.003 & 0.079 & -0.038 & 0.111 & -0.212 \\
\hline & $(0.173)$ & $(0.173)$ & $(0.183)$ & $(0.104)$ & $(0.146)$ & $(0.033)$ & $(0.204)$ & $(0.136)$ \\
\hline \multirow[t]{2}{*}{ Constant } & $\begin{array}{c}19.381 * \\
*\end{array}$ & $80.619 * * *$ & $24.483 * * *$ & $11.493 * *$ & 2.564 & $\begin{array}{c}7.427^{* *} \\
*\end{array}$ & 12.219 & $43.016 * * *$ \\
\hline & $(8.882)$ & $(8.882)$ & $(8.594)$ & $(5.260)$ & $(6.239)$ & $(1.962)$ & $(9.840)$ & $(6.320)$ \\
\hline Observations & 435 & 435 & 453 & 453 & 451 & 452 & 452 & 437 \\
\hline R-squared & 0.163 & 0.163 & 0.126 & 0.156 & 0.104 & 0.183 & 0.052 & 0.064 \\
\hline \multirow{2}{*}{$\begin{array}{l}\text { Number of countries } \\
\text { sigma }\end{array}$} & 26 & 26 & 27 & 27 & 27 & 27 & 27 & 26 \\
\hline & 18.358 & 18.358 & 18.358 & 18.358 & 18.358 & 18.358 & 18.358 & 18.358 \\
\hline
\end{tabular}

Notes: Heteroskedasticity-robust standard errors in parentheses. $* * * p<0.01, * * p<0.05, *<p 0.1$. The dependent variables are the components of GBAORD as percentage of Total GBAORD for Defence and Civil GBAORD, and as a percentage of Civil GBAORD for the rest. Data: 1995-2015. 
Table 6 : Share of GBAORD assigned to civil purposes, by EU membership and Innovation Union Scoreboard class

\begin{tabular}{|c|c|c|c|c|c|}
\hline $\begin{array}{l}\text { Dependent variable: } \\
\% \text { of GBAORD for civil purposes }\end{array}$ & $\begin{array}{l}(1) \\
E U\end{array}$ & $\begin{array}{c}(2) \\
\text { Non-EU }\end{array}$ & $\begin{array}{c}\text { (3) } \\
\text { Innovation Leader }\end{array}$ & $\begin{array}{c}\text { (4) } \\
\text { Innovation Follower }\end{array}$ & $\begin{array}{c}\text { (5) } \\
\text { Moderate Innovator }\end{array}$ \\
\hline \multirow[t]{2}{*}{ GRGDP (t-1) } & 0.230 & -0.027 & -0.003 & 0.010 & $0.115^{*}$ \\
\hline & $(0.139)$ & $(0.156)$ & $(0.271)$ & $(0.097)$ & $(0.058)$ \\
\hline \multirow[t]{2}{*}{ RECESSION } & 0.407 & -1.764 & 2.942 & 0.599 & 2.045 \\
\hline & $(0.835)$ & $(0.889)$ & $(4.834)$ & $(0.942)$ & $(3.001)$ \\
\hline \multirow[t]{2}{*}{ SURPLUS (t-1) } & -0.020 & $0.335^{*}$ & -0.402 & 0.092 & -0.211 \\
\hline & $(0.112)$ & $(0.131)$ & $(0.430)$ & $(0.144)$ & $(0.174)$ \\
\hline \multirow[t]{2}{*}{ RECESSION $\times$ SURPLUS (t-1)) } & -0.025 & $-0.415^{*}$ & 0.192 & -0.198 & 0.144 \\
\hline & (0.191) & $(0.153)$ & $(0.424)$ & $(0.254)$ & $(0.416)$ \\
\hline \multirow[t]{2}{*}{ GOVEXP ( $\mathrm{t}$} & 0.249 & $-0.321 *$ & $-0.730 * *$ & 0.046 & 0.079 \\
\hline & $(0.179)$ & $(0.107)$ & $(0.170)$ & $(0.157)$ & $(0.215)$ \\
\hline \multirow[t]{2}{*}{ Constant } & $79.440 * * *$ & $94.306 * * *$ & $131.618^{* * *}$ & $88.944 * * *$ & $88.195^{* * *}$ \\
\hline & $(9.769)$ & $(4.193)$ & $(10.050)$ & $(6.654)$ & $(10.212)$ \\
\hline Observations & 364 & 71 & 75 & 289 & 118 \\
\hline R-squared & 0.197 & 0.632 & 0.450 & 0.141 & 0.264 \\
\hline Number of countries & 22 & 4 & 4 & 18 & 8 \\
\hline sigma & 6.034 & 6.034 & 6.034 & 6.034 & 6.034 \\
\hline
\end{tabular}

Notes: Heteroskedasticity robust standard errors in parentheses. ${ }^{* *} p<0.01, * * p<0.05, * p<0.1$. The dependent variables are the share of civil GBAORD as percentage of Total GBAORD Year dummies are included 
Table 6 presents split sample estimates for EU versus non-EU countries (column 1-2), and EU countries according to their innovation status according to the Innovation Union Scoreboard (column 3-5). Regarding the first group, we find in non-EU countries a weakly significant positive relation between public surplus and civil GBAORD: a one percentage point increase in public surplus (or reduction in public deficit) as share of GDP relates to a 0.3 percentage point increase in the share of GBAORD allocated to civil purposes $(p<0.10)$. However, during recessions the relation reverses and an increase in government surplus is disproportionately allocated to defence GBAORD $(p<0.10)$. The splits based on innovation status show no large differences in countries' response to recessions. However, it is interesting to note that among moderate innovators, the relation between the share of GBAORD allocated to civil purposes is significantly dependent on GDP growth $(p<0.10)$, while this is not the case among innovation leaders or innovation followers.

\subsection{Public R\&D Expenditures by Beneficiaries}

This last subsection is aimed at answering whether governments redistribute public R\&D expenditures during economic crises across different beneficiaries. Table 7 presents estimation results for government financed R\&D in the business sector, government sector and higher education sector using model 4 (see section 3.2).

A clear pattern emerges from these different regressions: First, there is very high true state dependence in the shares of public R\&D expenditures by beneficiaries. Persistence is particularly high for government financed $R \& D$ in the higher education sector with a coefficient of the lagged dependent variable of 0.99 and higher. For specification (2) the estimate is even slightly above 1 reflecting the steady increase in this share over the period 1995 to 2014. State dependence is only slightly lower for intramural R\&D activities with a coefficient of the lagged dependent variable of 0.95 and higher. These high values are not surprising given the fact that public R\&D is mainly devoted to financing researchers in the government and higher education sector. Persistence is somewhat lower for government support for R\&D in the business sector but still high.

Second, there is hardly any evidence for redistributing public R\&D expenditures across beneficiaries which can be traced back to the business cycle. None of the variables capturing business cycle effects turned out to be significant. The change in the evolution of the corresponding shares over time (see Figure 9), showing an increasing long-run trend for public R\&D expenditures in the higher education sector, is unrelated to business cycle effects. 
Table 7: Model 4: Impact of Business Cycle on Public R\&D Investment by Beneficiaries

\begin{tabular}{|c|c|c|c|c|c|c|c|c|c|c|c|c|}
\hline & \multicolumn{4}{|c|}{ Business R\&D financed by Gov (BPubRD) } & \multicolumn{4}{|c|}{ Gov. intramural R\&D financed by Gov (GVPubRD) } & \multicolumn{4}{|c|}{ Higher Education R\&D financed by Gov (HPubRD) } \\
\hline & $\begin{array}{c}\text { Pooled } \\
\text { OLS } \\
(1) \\
\end{array}$ & $\begin{array}{c}\text { System } \\
\text { GMM } \\
(2) \\
\end{array}$ & $\begin{array}{c}\text { Pooled } \\
\text { OLS } \\
(3)\end{array}$ & $\begin{array}{c}\text { System } \\
\text { GMM } \\
(4)\end{array}$ & $\begin{array}{c}\text { Pooled } \\
\text { OLS } \\
(5) \\
\end{array}$ & $\begin{array}{c}\text { System } \\
\text { GMM } \\
(6)\end{array}$ & $\begin{array}{c}\text { Pooled } \\
\text { OLS } \\
(7)\end{array}$ & $\begin{array}{c}\text { System } \\
\text { GMM } \\
(8)\end{array}$ & $\begin{array}{l}\text { Pooled } \\
\text { OLS } \\
(9)\end{array}$ & $\begin{array}{c}\text { System } \\
\text { GMM } \\
(10)\end{array}$ & $\begin{array}{c}\text { Pooled } \\
\text { OLS } \\
(11)\end{array}$ & $\begin{array}{c}\text { System } \\
\text { GMM } \\
(12)\end{array}$ \\
\hline$B / G V / H P u b R D(t-1)$ & $\begin{array}{c}0.950^{* * *} \\
(0.025)\end{array}$ & $\begin{array}{c}0.898^{* * *} \\
(0.071)\end{array}$ & $\begin{array}{c}0.948^{* * *} \\
(0.028)\end{array}$ & $\begin{array}{c}0.835^{* * *} \\
(0.134)\end{array}$ & $\begin{array}{c}0.969 * * * \\
(0.009)\end{array}$ & $\begin{array}{c}0.953^{* * *} \\
(0.045)\end{array}$ & $\begin{array}{c}0.967 * * * \\
(0.009)\end{array}$ & $\begin{array}{c}0.985 * * * \\
(0.125)\end{array}$ & $\begin{array}{c}0.992^{* * *} \\
(0.010)\end{array}$ & $\begin{array}{c}1.078^{* * * *} \\
(0.240)\end{array}$ & $\begin{array}{c}0.990 * * * \\
(0.010)\end{array}$ & $\begin{array}{c}0.804^{* * *} \\
(0.245)\end{array}$ \\
\hline $\ln G D P(\mathrm{t}-1)$ & $\begin{array}{l}-0.156 \\
(0.112)\end{array}$ & $\begin{array}{c}0.156 \\
(0.261)\end{array}$ & $\begin{array}{l}-0.099 \\
(0.108)\end{array}$ & $\begin{array}{c}0.302 \\
(0.493)\end{array}$ & $\begin{array}{c}0.147 \\
(0.087)\end{array}$ & $\begin{array}{c}0.043 \\
(0.098)\end{array}$ & $\begin{array}{c}0.117 \\
(0.101)\end{array}$ & $\begin{array}{c}0.000 \\
(0.000)\end{array}$ & $\begin{array}{c}0.112 \\
(0.116)\end{array}$ & $\begin{array}{l}-2.791 \\
(6.273)\end{array}$ & $\begin{array}{c}0.093 \\
(0.128)\end{array}$ & $\begin{array}{c}3.993 \\
(3.312)\end{array}$ \\
\hline SURPLUS (t-1) & $\begin{array}{l}-0.027 \\
(0.041)\end{array}$ & $\begin{array}{l}-0.034 \\
(0.069)\end{array}$ & $\begin{array}{l}-0.041 \\
(0.038)\end{array}$ & $\begin{array}{l}-0.057 \\
(0.056)\end{array}$ & $\begin{array}{l}-0.004 \\
(0.023)\end{array}$ & $\begin{array}{c}0.008 \\
(0.037)\end{array}$ & $\begin{array}{l}-0.004 \\
(0.025)\end{array}$ & $\begin{array}{l}-0.036 \\
(0.207)\end{array}$ & $\begin{array}{c}0.014 \\
(0.046)\end{array}$ & $\begin{array}{c}0.071 \\
(0.076)\end{array}$ & $\begin{array}{c}0.024 \\
(0.054)\end{array}$ & $\begin{array}{l}-0.050 \\
(0.163)\end{array}$ \\
\hline$D E B T(\mathrm{t}-1)$ & $\begin{array}{l}-0.001 \\
(0.004)\end{array}$ & $\begin{array}{l}-0.005 \\
(0.006)\end{array}$ & $\begin{array}{l}-0.001 \\
(0.005)\end{array}$ & $\begin{array}{l}-0.009 \\
(0.008)\end{array}$ & $\begin{array}{c}0.002 \\
(0.004)\end{array}$ & $\begin{array}{c}0.004 \\
(0.005)\end{array}$ & $\begin{array}{l}0.000 \\
(0.004)\end{array}$ & $\begin{array}{c}0.000 \\
(0.021)\end{array}$ & $\begin{array}{l}-0.006 \\
(0.005)\end{array}$ & $\begin{array}{c}0.001 \\
(0.012)\end{array}$ & $\begin{array}{l}-0.004 \\
(0.006)\end{array}$ & $\begin{array}{l}-0.004 \\
(0.016)\end{array}$ \\
\hline$I R(\mathrm{t})$ & $\begin{array}{c}0.051 \\
(0.073)\end{array}$ & $\begin{array}{c}0.126 \\
(0.103)\end{array}$ & $\begin{array}{c}0.037 \\
(0.073)\end{array}$ & $\begin{array}{c}0.113 \\
(0.082)\end{array}$ & $\begin{array}{l}-0.018 \\
(0.073)\end{array}$ & $\begin{array}{c}0.060 \\
(0.158)\end{array}$ & $\begin{array}{l}-0.003 \\
(0.067)\end{array}$ & $\begin{array}{c}0.002 \\
(0.672)\end{array}$ & $\begin{array}{l}-0.006 \\
(0.055)\end{array}$ & $\begin{array}{l}-0.024 \\
(0.142)\end{array}$ & $\begin{array}{l}-0.005 \\
(0.058)\end{array}$ & $\begin{array}{l}-0.181 \\
(0.275)\end{array}$ \\
\hline RECESSION (t-1) & & & $\begin{array}{l}7.980^{*} \\
(3.890)\end{array}$ & $\begin{array}{c}9.709 \\
(11.778)\end{array}$ & & & $\begin{array}{l}-4.853^{*} \\
(2.775)\end{array}$ & $\begin{array}{c}0.000 \\
(0.000)\end{array}$ & & & $\begin{array}{l}-2.487 \\
(2.687)\end{array}$ & $\begin{array}{l}-12.322 \\
(50.959)\end{array}$ \\
\hline In GDP $\times$ RECESSION (t-1) & & & $\begin{array}{l}-0.541^{*} \\
(0.293)\end{array}$ & $\begin{array}{l}-0.675 \\
(0.875)\end{array}$ & & & $\begin{array}{c}0.316 \\
(0.219)\end{array}$ & $\begin{array}{l}-0.112 \\
(0.148)\end{array}$ & & & $\begin{array}{c}0.177 \\
(0.226)\end{array}$ & $\begin{array}{c}0.990 \\
(3.954)\end{array}$ \\
\hline SURPLUS $\times$ RECESSION (t-1) & & & $\begin{array}{c}0.143 \\
(0.085)\end{array}$ & $\begin{array}{c}0.107 \\
(0.102)\end{array}$ & & & $\begin{array}{l}-0.013 \\
(0.067)\end{array}$ & $\begin{array}{l}0.365 \\
(1.083)\end{array}$ & & & $\begin{array}{l}-0.104 \\
(0.065)\end{array}$ & $\begin{array}{l}-0.116 \\
(0.598)\end{array}$ \\
\hline$D E B T \times R E C E S S I O N(\mathrm{t}-1)$ & & & $\begin{array}{c}0.004 \\
(0.009)\end{array}$ & $\begin{array}{l}-0.005 \\
(0.015)\end{array}$ & & & $\begin{array}{c}0.006 \\
(0.010)\end{array}$ & $\begin{array}{c}0.029 \\
(0.048)\end{array}$ & & & $\begin{array}{l}-0.009 \\
(0.010)\end{array}$ & $\begin{array}{l}-0.027 \\
(0.073)\end{array}$ \\
\hline Constant & $\begin{array}{l}2.471^{*} \\
(1.369)\end{array}$ & $\begin{array}{l}-1.283 \\
(3.501)\end{array}$ & $\begin{array}{l}1.747 \\
(1.146)\end{array}$ & $\begin{array}{l}-2.309 \\
(6.998) \\
\end{array}$ & $\begin{array}{l}-1.598 \\
(1.103) \\
\end{array}$ & $\begin{array}{c}0.000 \\
(0.000) \\
\end{array}$ & $\begin{array}{l}-1.060 \\
(1.339)\end{array}$ & $\begin{array}{c}0.000 \\
(0.000)\end{array}$ & $\begin{array}{l}-0.072 \\
(1.768)\end{array}$ & $\begin{array}{c}34.677 \\
(74.968) \\
\end{array}$ & $\begin{array}{c}0.188 \\
(1.801)\end{array}$ & $\begin{array}{l}-42.098 \\
(31.368) \\
\end{array}$ \\
\hline R-squared & 0.906 & & 0.908 & & 0.966 & & 0.966 & & 0.972 & & 0.972 & \\
\hline J & $\cdot$ & 11.294 & $\cdot$ & 8.579 & $\cdot$ & 17.656 & $\cdot$ & 16.052 & $\cdot$ & 16.763 & $\cdot$ & 11.745 \\
\hline $\begin{array}{l}p \text {-value } \\
\text { AR1 (p-value) }\end{array}$ & . & $\begin{array}{l}1.000 \\
0.012\end{array}$ & . & $\begin{array}{l}1.000 \\
0.018\end{array}$ & . & $\begin{array}{l}1.000 \\
0.005\end{array}$ & . & $\begin{array}{l}1.000 \\
0.016\end{array}$ & . & $\begin{array}{l}1.000 \\
0.015\end{array}$ & . & $\begin{array}{l}1.000 \\
0.027\end{array}$ \\
\hline $\begin{array}{l}\text { AR1 ( } p \text {-value) } \\
\text { AR2 ( } p \text {-value) }\end{array}$ & $\dot{\cdot}$ & $\begin{array}{l}0.012 \\
0.265\end{array}$ & $\dot{\cdot}$ & $\begin{array}{l}0.018 \\
0.254\end{array}$ & $\cdot$ & $\begin{array}{l}0.005 \\
0.156\end{array}$ & $\dot{r}$ & $\begin{array}{l}0.016 \\
0.157\end{array}$ & $\cdot$ & 0.432 & $\cdot$ & 0.803 \\
\hline Observations & 286 & 286 & 286 & 286 & 286 & 286 & 286 & 286 & 286 & 286 & 286 & 286 \\
\hline No. of countries & 21 & 21 & 21 & 21 & 21 & 21 & 21 & 21 & 21 & 21 & 21 & 21 \\
\hline
\end{tabular}

Notes: $* * * p<0.01, * * p<0.05, * p<0.1$. Clustered standard errors in parentheses for pooled OLS and Windmijer finite-sample corrected standard errors for System GMM. 


\section{Conclusion}

Recently, a growing number of papers have studied the impact of the 2008/2009 financial and economic crisis on firms' R\&D activities. This paper takes a different approach by studying the impact of economic crises on government financed R\&D activities for a sample of 26 OECD countries over the period 1995 to 2015. In particular, we addressed three different research questions: First, do economic crises influence the overall level and growth of public R\&D expenditures? Second, do economic crises lead to any shifts in the composition of public R\&D expenditures across different thematic areas? And third, are there any business cycle induced redistributions across different beneficiaries of public R\&D expenditure. Our analysis makes use of two different measures for government financed R\&D: GBAORD and public R\&D expenditures calculated using different components of gross domestic expenditures on R\&D.

We observe a high persistence in government financed R\&D activities which means that public R\&D spending only change gradually. But in addition our results demonstrate that there is strong procyclical effect on public R\&D investments. An increase in GDP by 1 percent leads to a subsequent increase for instance in GBAORD by roughly 0.15 to 0.2 percent. The econometric results furthermore show that the growth rate of GBAORD is on average 2.5 percentage points lower in a recession than in a non-recession. There is, however, impressive evidence that countries react differently to recessions. In particular, European innovation leaders pursue a counter-cyclical strategy and increase growth of GBOARD during a recession. A similar though somewhat less pronounced counter-cyclical strategy is shown for the non-EU countries considered in this study (Australia, Canada, Israel, Japan, South Korea and the US). In contrast, innovation followers and moderate innovators clearly follow a pro-cyclical pattern. That is, they cut public R\&D expenditures significantly during recessions. As a result, we have observed an increasing innovation gap between innovation leaders and moderate innovators in Europe due to the most recent 2008 crisis. As innovation is a major driver of productivity and growth, this increased innovation gap might lead to stronger productivity differences across these different country groups in the long-run.

Our results furthermore show that governments' short-run and long-run financing conditions affect public R\&D spending significantly. A loosening of budget constraints allows governments to intensify their R\&D strategy and finance more R\&D activities, either in the government sector or in the higher education and business sector. As a result, we observe that an increase in the surplus to GDP ratio (or a reduction in the deficit to GDP ratio) by 1 percentage point, stimulates GBAORD by 0.6 to 0.8 percent in the short-run. But governments face a trade-off when using an increase in budget surplus for additional spending. Alternatively, they could have used it to repay debts. Increasing government debt levels on the contrary have led to reductions in public R\&D spending in the period under consideration. High levels of debt exert a strong pressure to consolidate public budgets so that spending for R\&D is likely to be cut as well. The pressure to reduce public debt levels is currently observed in most European countries so that R\&D budgets are likely to contribute to fiscal consolidation in the future.

Concerning the second research question, our analysis does not support the hypothesis that economic crises systematically affect the composition of GBAORD spending along 7 thematic areas. That is, differences in the level of GBAORD seem to proportionally reduce spending in each category, and do 
not lead to some areas being cut disproportionally. Rather, the composition of GBAORD seems to be subject to longer-run trends.

A similar conclusion can be drawn for the third research question concerning the composition of public $R \& D$ expenditures by beneficiaries. Our analysis does not provide any evidence for a business cycle induced redistribution of public R\&D expenditures across beneficiaries. The observed long-run shift towards financing disproportionally more R\&D in the higher education sector compared to R\&D in the business and government sector is subject to a shift in governments' strategy but not related to any business cycle effects.

In a nutshell, our results corroborate that the recent 2008/2009 financial and economic crisis and the sluggish recovery in many countries states had a severe and still lasting impact on the ability of governments to invest into R\&D. 


\section{References}

Abbott, A., P. Jones (2011), Pro-cyclical government spending: patterns of pressure and prudence in the OECD, Economic Letters 111, 230-232.

Aghion, P., G. Saint-Paul (1998), Virtues of bad times: interaction between productivity growth and economic fluctuations, Macroeconomic Dynamics 2(3), 322-344.

Aghion, P., G.M. Angeletos, A. Banerjee, K. Manova (2010), Volatility and growth: credit constraints and the composition of investment, Journal of Monetary Economics 57(3), 246-265.

Aghion, P., P. Ashkenazy, N. Berman, L. Eymard, G. Cette (2012), Credit constraints and the cyclicality of R\&D investment: evidence from France, Journal of the European Economic Association 10(5), 1001-1024.

Alesina, A., F. Campante, G. Tabellini (2008), Why is fiscal policy often procyclical? Journal of the European Economic Association 6, 1006-1036.

Arellano, M., S. Bond (1991), Some Tests of Specification for Panel Data: Monte Carlo Evidence and an Application to Employment Equations, Review of Economic Studies 58 (2), 277-297.

Arellano, M., O. Bover (1995), Another look at the instrumental variable estimation of errorcomponents models, Journal of Econometrics 68, 29-51.

Arreaza, A., B.E. Sorensen, O. Yosha (1999), Consumption smoothing through fiscal policy in OECD and EU countries, in J.M. Poterba, J. Hagen (eds.), Fiscal Institutions and Fiscal Performance, Chicago: University of Chicago Press, 59-80.

Arvanitis, S., M. Woerter (2014), Firm characteristics and the cyclicality of R\&D investments, Industrial and Corporate Change 13, 1141-1169.

Barlevy, G. (2007), On the cyclicality of research and development, American Economic Review 97(4), 1131-1164.

Bean, C.R. (1990), Endogenous growth and the procyclical behaviour of productivity, European Economic Review 34(2), 355-363.

Blundell, R., S. Bond (1998), Initial conditions and moment restrictions in dynamic panel data models, Journal of Econometrics 87, 115-143.

Bond, S. (2002), Dynamic panel data models: a guide to microdata methods and practice, Cemmap Working Paper (CWP09/02), London.

Bovha-Padilla, S., J.P. Damijan, J. Konings (2009), Financial constraints and the cyclicality of R\&D investment: Evidence from Slovenia, LICOS Discussion Paper 239/2009.

David, P.A., B.H. Hall, A.A. Toole (2000), Is public R\&D a complement or substitute for private R\&D? A Review of the Econometric Evidence, Research Policy 29, 497-529.

European Commission (2011), Effect of the economic crisis on R\&D investment, in: European Commission (ed.), Innovation Union Competitiveness Report 2011, Luxembourg, 60-72.

European Commission (2015), Innovation Union Scoreboard 2015, Belgium.

Fabrizio, K.R., U. Tsolmon (2014), An empirical examination of the procyclicality of R\&D investment and innovation, Review of Economics and Statistics 96(4), 662-675. 
Fatas, A. (2000), Do business cycles cast long shadows? Short-run persistence and economic growth, Journal of Economic Growth 5(2), 147-162.

Filippetti, A., D. Archibugi (2011), Innovation in times of crises: national systems of innovation, structure and demand, Research Policy 40, 179-192.

Francois, P., H. Lloyd-Ellis (2003), Animal spirits through creative destruction, American Economic Review 93, 530-550.

Francois, P., H. Lloyd-Ellis (2009), Schumpeterian cycles with pro-cyclical R\&D, Review of Economic Dynamics 12, 567-591.

Fuest, C., G. Licht (2014), The Impact of the Financial and Economic Crisis on Public R\&D Spending, Report produced for the I4G Expert Group, Mannheim.

Gali, J., M.L. Hammour (1991), Long-run Effects of Business Cycles. Discussion Papers 1991-18, Columbia University, Department of Economics.

Geroski, P.A., C.F. Walters (1995), Innovative activity over the business cycle, Economic Journal 105, 916-928.

Giebel, M., K. Kraft (2015), The Impact of the Financial Crisis on Investments in Innovative Firms, ZEW Discussion Paper 15-069, Mannheim.

Hud, M., K. Hussinger (2015), The Impact of R\&D Subsidies during the Crisis, Research Policy 44, 18441855.

Hud, M., C. Rammer (2015), Innovation Budgeting Over the Business Cycle and Innovation Performance, ZEW Discussion Paper 15-030, Mannheim.

Izsak, K., P. Markianidou, R. Lukach, A. Wastyn (2013), The Impact of the Crisis on Research and Innovation Policies, Brussels: Technopolis Group Belgium and Idea Consult.

Kim, S.Y. (2014), Government R\&D funding in economic downturns: testing the varieties of capitalism conjecture, Science and Public Policy 41, 107-118.

Lane, P. (2003), The Cyclical Behaviour of Fiscal Policy: Evidence from the OECD, Journal of Public Economics 87, 2661-2675.

López-Garcia, P., J.M. Montero, E. Moral-Benito (2012), Business Cycles and Investment in Intangibles: Evidence from Spanish Firms. Banco De Espana Working Paper No. 1219.

Makkonen, T. (2013), Government science and technology budgets in times of crisis, Research Policy $42,817-822$.

OECD (2012), Innovation in the crisis and beyond, in: OECD (ed.), Science, Technology and Industry Outlook 2012, Paris, 21-57.

Ouyang, M. (2011), On the cyclicality of R\&D, Review of Economics and Statistics 93(2), 542-553.

Rafferty, M., M. Funk (2008), Asymmetric effects of the business cycle on firm-financed R\&D, Economics of Innovation and New Technology 17(5), 497-510.

Romer, D. (1993), The New Keynesian Synthesis, Journal of Economic Perspectives 7, 5-22.

Shleifer, A. (1986), Implementation cycles, Journal of Political Economy 94(6), 1163-1190.

Saint-Paul, G. (1993), Productivity growth and the structure of the business cycle, European Economic Review 37(4), 861-890. 
Veugelers, R. (2016), Getting the Most from Public R\&D Spending in Times of Austerity: Some Insights from SIMPATIC Analysis, Breugel Working Paper 2016/1, Brussels.

Veugelers, R. (2014), Is Europe Saving Away its Future? European Public Funding for Research in the Era of Fiscal Consolidation, Policy Brief by the Research, Innovation, and Science Policy Experts (RISE), Brussels; European Commission.

Wälde, K., U. Woitek (2004), R\&D expenditure in G7 countries and implications for endogenous fluctuations and growth, Economics Letters 82(1), 91-97. 


\section{Appendix}

Figure A.1: GBAORD and Public R\&D Expenditure in \% of GDP by Country, 1995-2015

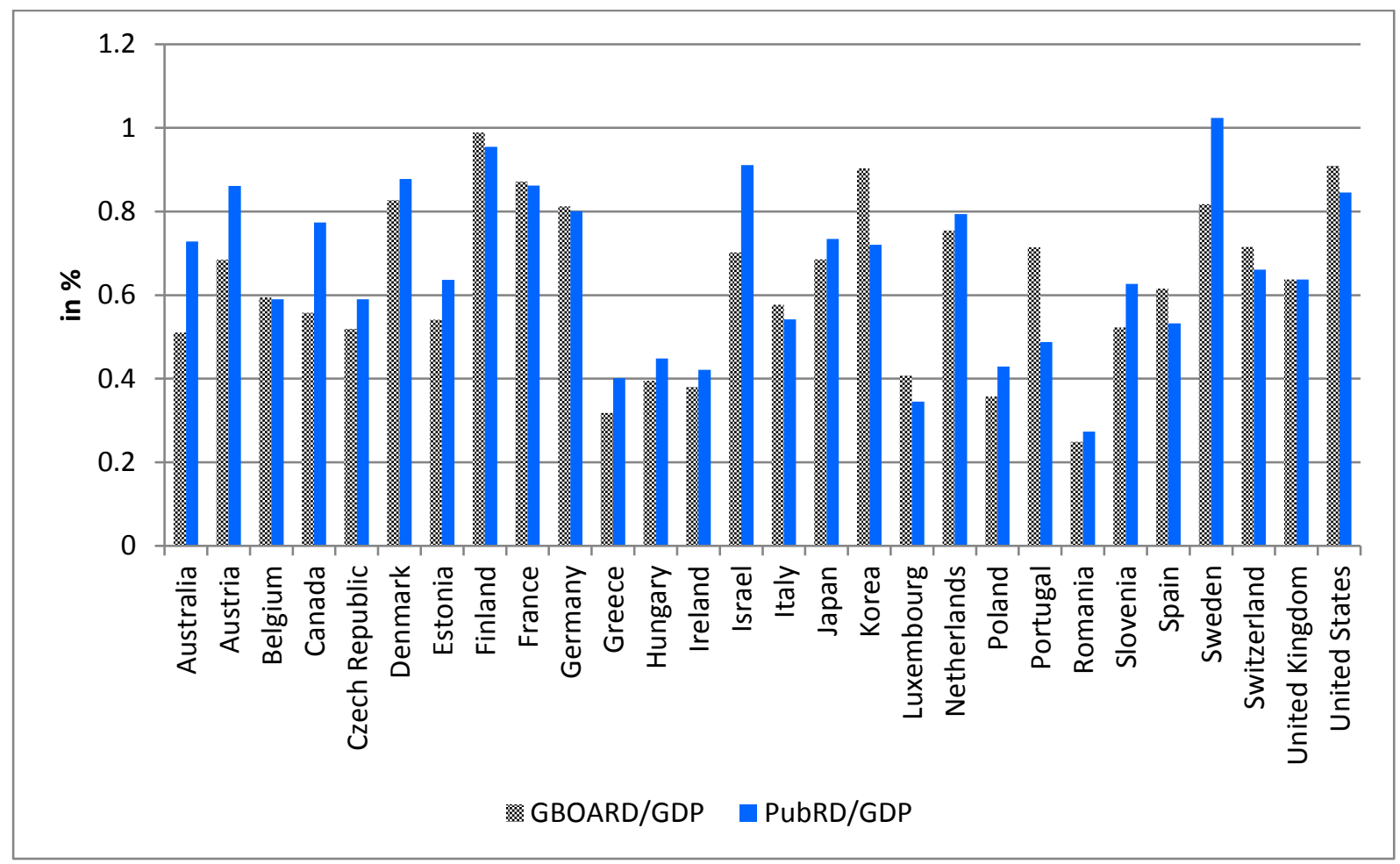

Figure A.2: Average Annual Growth Rate of GBAORD by Country, 1995-2015

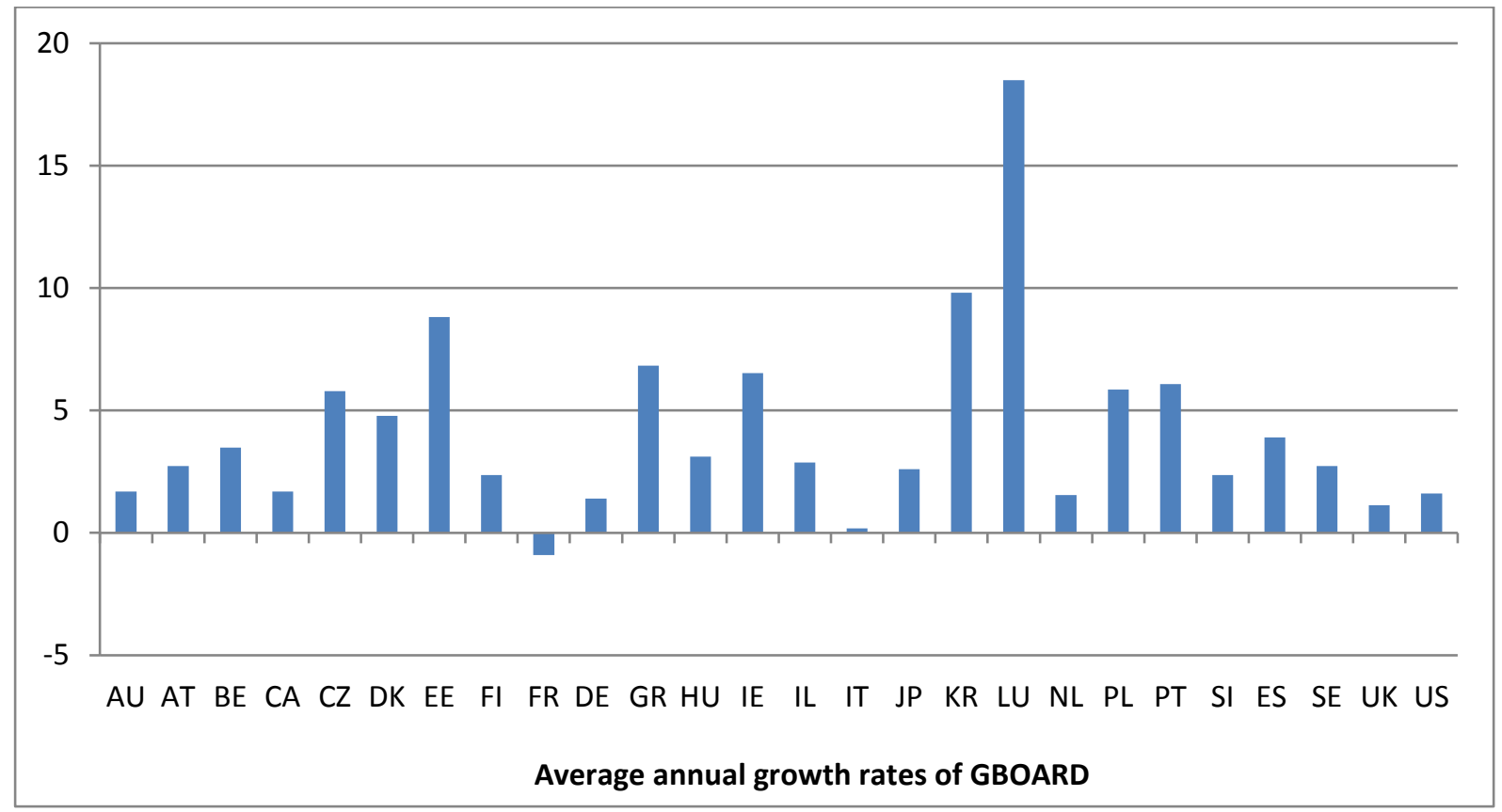


Table A.1: Model 1 - Robustness Checks

\begin{tabular}{|c|c|c|c|c|c|c|c|c|c|c|}
\hline & \multicolumn{2}{|c|}{ 4-phase BC indicator } & \multicolumn{2}{|c|}{ 2-phase BC indicator } & \multicolumn{2}{|c|}{ GDP growth } & \multicolumn{4}{|c|}{ EIS country groups } \\
\hline & $\begin{array}{l}\text { GBAORD } \\
\text { (1) }\end{array}$ & $\begin{array}{c}\text { PubRD } \\
\text { (2) }\end{array}$ & $\begin{array}{l}\text { GBAORD } \\
\text { (3) }\end{array}$ & $\begin{array}{c}\text { PubRD } \\
\text { (4) }\end{array}$ & $\begin{array}{c}\text { GBAORD } \\
\text { (5) }\end{array}$ & $\begin{array}{c}\text { PubRD } \\
(6)\end{array}$ & $\begin{array}{c}\text { GBAORD } \\
\text { (7) }\end{array}$ & $\begin{array}{c}\text { PubRD } \\
\text { (8) }\end{array}$ & $\begin{array}{c}\text { GBAORD } \\
\text { (9) }\end{array}$ & $\begin{array}{l}\text { PubRD } \\
\text { (10) }\end{array}$ \\
\hline $\ln G B A O R D(\mathrm{t}-1)$ & $\begin{array}{c}0.994 * * * \\
(0.023)\end{array}$ & $\begin{array}{c}1.009 * * * \\
(0.028)\end{array}$ & $\begin{array}{c}0.996 * * * \\
(0.024)\end{array}$ & $\begin{array}{c}1.002^{* * *} \\
(0.033)\end{array}$ & $\begin{array}{c}0.994 * * * \\
(0.020)\end{array}$ & $\begin{array}{c}0.987 * * * \\
(0.037)\end{array}$ & $\begin{array}{c}0.708^{* * *} \\
(0.177)\end{array}$ & $\begin{array}{c}0.942 * * * \\
(0.249)\end{array}$ & $\begin{array}{c}0.807 * * * \\
(0.231)\end{array}$ & $\begin{array}{l}0.783^{* *} \\
(0.376)\end{array}$ \\
\hline $\ln G D P(\mathrm{t}-1)$ & & & & & & & $\begin{array}{c}0.328 \\
(0.200)\end{array}$ & $\begin{array}{c}0.032 \\
(0.294)\end{array}$ & $\begin{array}{c}0.226 \\
(0.263)\end{array}$ & $\begin{array}{c}0.241 \\
(0.423)\end{array}$ \\
\hline SURPLUS (t-1) & $\begin{array}{c}0.004^{* * *} \\
(0.002)\end{array}$ & $\begin{array}{c}0.002 \\
(0.002)\end{array}$ & $\begin{array}{c}0.006^{* * *} \\
(0.002)\end{array}$ & $\begin{array}{c}0.002 \\
(0.002)\end{array}$ & $\begin{array}{c}0.006^{* * *} \\
(0.001)\end{array}$ & $\begin{array}{c}0.003 \\
(0.002)\end{array}$ & $\begin{array}{c}0.004 * * \\
(0.002)\end{array}$ & $\begin{array}{c}0.002 \\
(0.005)\end{array}$ & $\begin{array}{l}0.007^{*} \\
(0.004)\end{array}$ & $\begin{array}{c}0.003 \\
(0.003)\end{array}$ \\
\hline$D E B T(\mathrm{t}-1)$ & $\begin{array}{l}-0.001 \\
(0.000)\end{array}$ & $\begin{array}{c}-0.001^{*} \\
(0.001)\end{array}$ & $\begin{array}{l}-0.000 \\
(0.000)\end{array}$ & $\begin{array}{l}-0.001 \\
(0.001)\end{array}$ & $\begin{array}{l}-0.000 \\
(0.000)\end{array}$ & $\begin{array}{l}-0.000 \\
(0.001)\end{array}$ & $\begin{array}{l}-0.000 \\
(0.000)\end{array}$ & $\begin{array}{l}-0.001 \\
(0.001)\end{array}$ & $\begin{array}{l}-0.000 \\
(0.000)\end{array}$ & $\begin{array}{l}-0.000 \\
(0.002)\end{array}$ \\
\hline$I R(\mathrm{t})$ & $\begin{array}{l}-0.003 \\
(0.004)\end{array}$ & $\begin{array}{c}-0.011^{* *} \\
(0.005)\end{array}$ & $\begin{array}{c}0.000 \\
(0.004)\end{array}$ & $\begin{array}{l}-0.008 \\
(0.006)\end{array}$ & $\begin{array}{c}0.002 \\
(0.003)\end{array}$ & $\begin{array}{l}-0.005 \\
(0.004)\end{array}$ & $\begin{array}{l}-0.002 \\
(0.004)\end{array}$ & $\begin{array}{l}-0.010 \\
(0.008)\end{array}$ & $\begin{array}{c}0.000 \\
(0.006)\end{array}$ & $\begin{array}{l}-0.005 \\
(0.008)\end{array}$ \\
\hline$B O O M(\mathrm{t}-1)$ & $\begin{array}{c}0.013 \\
(0.017)\end{array}$ & $\begin{array}{c}0.009 \\
(0.023)\end{array}$ & & & & & & & & \\
\hline DOWNTURN (t-1) & $\begin{array}{c}0.020 * * \\
(0.009)\end{array}$ & $\begin{array}{l}-0.003 \\
(0.008)\end{array}$ & & & & & & & & \\
\hline RECESSION $(\mathrm{t}-1)$ & $\begin{array}{c}-0.010 \\
(0.018)\end{array}$ & $\begin{array}{l}-0.005 \\
(0.018)\end{array}$ & & & & & $\begin{array}{c}0.009 \\
(0.021)\end{array}$ & $\begin{array}{l}-0.005 \\
(0.026)\end{array}$ & $\begin{array}{l}-0.152 \\
(0.293)\end{array}$ & $\begin{array}{c}0.043 \\
(0.283)\end{array}$ \\
\hline$D O W N(\mathrm{t}-1)$ & & & $\begin{array}{c}0.018 * * \\
(0.008)\end{array}$ & $\begin{array}{c}0.001 \\
(0.007)\end{array}$ & & & & & & \\
\hline$G R G D P(\mathrm{t}-1)$ & & & & & $\begin{array}{l}-0.001 \\
(0.002)\end{array}$ & $\begin{array}{c}0.001 \\
(0.002)\end{array}$ & & & & \\
\hline Innov. Follower & & & & & & & $\begin{array}{l}-0.081 \\
(0.083)\end{array}$ & $\begin{array}{c}0.100 \\
(0.297)\end{array}$ & $\begin{array}{l}-0.048 \\
(0.103)\end{array}$ & $\begin{array}{c}0.063 \\
(0.429)\end{array}$ \\
\hline Moderate & & & & & & & $\begin{array}{l}-0.129 \\
(0.129)\end{array}$ & $\begin{array}{c}0.101 \\
(0.342)\end{array}$ & $\begin{array}{l}-0.066 \\
(0.149)\end{array}$ & $\begin{array}{c}0.099 \\
(0.491)\end{array}$ \\
\hline Non-EU & & & & & & & $\begin{array}{l}-0.118 \\
(0.104)\end{array}$ & $\begin{array}{c}0.253 \\
(0.497)\end{array}$ & $\begin{array}{l}-0.080 \\
(0.115)\end{array}$ & $\begin{array}{c}0.063 \\
(0.659)\end{array}$ \\
\hline RECESS $\times$ Follower & & & & & & & & & $\begin{array}{c}0.238 \\
(0.345)\end{array}$ & $\begin{array}{l}-0.068 \\
(0.162)\end{array}$ \\
\hline RECES $\times$ Moderate & & & & & & & & & $\begin{array}{c}0.165 \\
(0.373)\end{array}$ & $\begin{array}{l}-0.117 \\
(0.155)\end{array}$ \\
\hline RECES $\times$ Non-EU & & & & & & & & & $\begin{array}{c}0.201 \\
(0.379)\end{array}$ & $\begin{array}{c}0.052 \\
(0.062)\end{array}$ \\
\hline Constant & $\begin{array}{c}0.142 \\
(0.214)\end{array}$ & $\begin{array}{c}0.110 \\
(0.197)\end{array}$ & $\begin{array}{c}0.074 \\
(0.205)\end{array}$ & $\begin{array}{c}0.126 \\
(0.221)\end{array}$ & $\begin{array}{c}0.108 \\
(0.140)\end{array}$ & $\begin{array}{c}0.177 \\
(0.245)\end{array}$ & $\begin{array}{l}-1.810 \\
(1.164)\end{array}$ & $\begin{array}{c}0.111 \\
(1.862)\end{array}$ & $\begin{array}{l}-1.316 \\
(1.620)\end{array}$ & $\begin{array}{l}-1.386 \\
(2.352)\end{array}$ \\
\hline J (p-value) & 1.000 & 0.002 & 1.000 & 0.904 & 1.000 & 1.000 & 1.000 & 1.000 & 1.000 & 1.000 \\
\hline AR1 (p-value) & 0.007 & 0.999 & 0.006 & 0.002 & 0.006 & 0.001 & 0.023 & 0.027 & 0.024 & 0.113 \\
\hline AR2 (p-value) & 0.198 & 1.000 & 0.208 & 1.000 & 0.187 & 0.806 & 0.195 & 0.909 & 0.171 & 0.756 \\
\hline Observations & 412 & 286 & 412 & 286 & 412 & 286 & 412 & 286 & 412 & 286 \\
\hline
\end{tabular}

Notes: All estimates are based on System GMM. Windmijer finite-sample corrected standard errors. ${ }^{* * *} p<0.01, * * p<0.05,{ }^{*} p<0.1$. 
Table A.2: Dynamic panel estimates of composition of GBAORD

\begin{tabular}{|c|c|c|c|c|c|c|c|c|}
\hline VARIABLES & $\begin{array}{c}(1) \\
\text { Defence }\end{array}$ & $\begin{array}{c}(2) \\
\text { Civil } \\
\text { GBAORD }\end{array}$ & $\begin{array}{c}(3) \\
\text { Economic } \\
\text { Development }\end{array}$ & $\begin{array}{c}\text { (4) } \\
\text { Health \& } \\
\text { Environment }\end{array}$ & $\begin{array}{c}\text { (5) } \\
\text { Education \& } \\
\text { Social }\end{array}$ & $\begin{array}{l}(6) \\
\text { Space }\end{array}$ & $\begin{array}{c}\text { (7) } \\
\text { Non-oriented }\end{array}$ & $\begin{array}{c}\text { (8) } \\
\text { University Funds }\end{array}$ \\
\hline Dependent (t-1) & $\begin{array}{c}0.971 * * * \\
(0.022)\end{array}$ & $\begin{array}{c}0.972 * * * \\
(0.039)\end{array}$ & $\begin{array}{c}0.783 * * * \\
(0.128)\end{array}$ & $\begin{array}{c}0.893^{* * *} \\
(0.068)\end{array}$ & $\begin{array}{c}0.889 * * * \\
(0.014)\end{array}$ & $\begin{array}{c}0.962^{* * *} \\
(0.008)\end{array}$ & $\begin{array}{c}0.860 * * * \\
(0.069)\end{array}$ & $\begin{array}{c}0.857^{* * *} \\
(0.049)\end{array}$ \\
\hline$G R G D P(\mathrm{t}-1)$ & $\begin{array}{c}0.023 \\
(0.018)\end{array}$ & $\begin{array}{l}-0.023 \\
(0.019)\end{array}$ & $\begin{array}{c}0.067 \\
(0.065)\end{array}$ & $\begin{array}{l}-0.049 \\
(0.054)\end{array}$ & $\begin{array}{c}0.012 \\
(0.023)\end{array}$ & $\begin{array}{l}-0.000 \\
(0.010)\end{array}$ & $\begin{array}{c}0.013 \\
(0.081)\end{array}$ & $\begin{array}{c}0.018 \\
(0.052)\end{array}$ \\
\hline SURPLUS (t-1) & $\begin{array}{l}-0.020 \\
(0.023)\end{array}$ & $\begin{array}{c}0.031 \\
(0.038)\end{array}$ & $\begin{array}{c}0.112 \\
(0.097)\end{array}$ & $\begin{array}{l}-0.004 \\
(0.029)\end{array}$ & $\begin{array}{c}0.040 * * \\
(0.016)\end{array}$ & $\begin{array}{l}-0.025^{*} \\
(0.014)\end{array}$ & $\begin{array}{l}-0.020 \\
(0.047)\end{array}$ & $\begin{array}{l}-0.026 \\
(0.081)\end{array}$ \\
\hline $\operatorname{GOVEXP}(t)$ & $\begin{array}{l}-0.015 \\
(0.011)\end{array}$ & $\begin{array}{c}0.020 \\
(0.029)\end{array}$ & $\begin{array}{l}-0.024 \\
(0.115)\end{array}$ & $\begin{array}{l}-0.075 \\
(0.048)\end{array}$ & $\begin{array}{c}0.003 \\
(0.020)\end{array}$ & $\begin{array}{l}-0.004 \\
(0.005)\end{array}$ & $\begin{array}{l}-0.013 \\
(0.073)\end{array}$ & $\begin{array}{c}0.141 \\
(0.087)\end{array}$ \\
\hline Constant & $\begin{array}{c}0.563 \\
(0.520)\end{array}$ & $\begin{array}{c}2.085 \\
(3.492)\end{array}$ & $\begin{array}{c}6.317 \\
(7.447)\end{array}$ & $\begin{array}{l}5.018^{*} \\
(2.603)\end{array}$ & $\begin{array}{c}0.514 \\
(0.828)\end{array}$ & $\begin{array}{c}0.188 \\
(0.238)\end{array}$ & $\begin{array}{c}3.299 \\
(3.172)\end{array}$ & $\begin{array}{l}-2.595 \\
(3.835)\end{array}$ \\
\hline Observations & 417 & 417 & 435 & 435 & 433 & 435 & 435 & 420 \\
\hline Number of countries & 25 & 25 & 26 & 26 & 26 & 26 & 26 & 25 \\
\hline J & 17.894 & 17.894 & 17.894 & 17.894 & 17.894 & 17.894 & 17.894 & 17.894 \\
\hline$p$-value & 1.000 & 0.001 & 1.000 & 1.000 & 1.000 & 0.001 & 0.117 & 0.117 \\
\hline AR1 & -3.194 & -3.194 & -3.194 & -3.194 & -3.194 & -3.194 & -3.194 & -3.194 \\
\hline$p$-value & 0.001 & 0.117 & 0.001 & 0.001 & 0.001 & 0.117 & 1.000 & 0.001 \\
\hline AR2 & -1.567 & -1.567 & -1.567 & -1.567 & -1.567 & -1.567 & -1.567 & -1.567 \\
\hline$p$-value & 0.117 & 1.000 & 0.117 & 0.117 & 0.117 & 1.000 & 0.001 & 1.000 \\
\hline sigma & 3.175 & 3.175 & 3.175 & 3.175 & 3.175 & 3.175 & 3.175 & 3.175 \\
\hline
\end{tabular}

Notes: Heteroskedasticity-robust standard errors in parentheses. ${ }^{* *} \mathrm{p}<0.01, * * \mathrm{p}<0.05, *<\mathrm{p} 0.1$. The dependent variables are the components of GBAORD as percentage of Total GBAORD for Defence and Civil GBAORD, and as a percentage of Civil GBAORD for the rest. Estimation since year 1996 (same as GBAORD estimations). Independent variables are assumed exogenous. 